\title{
The Role of Toll-Like Receptors and Vitamin D in Cardiovascular Diseases-A Review
}

\author{
Daria M. Adamczak \\ Department of Cardiology, Poznan University of Medical Sciences, Dluga Street 1/2, 61-848 Poznan, Poland; \\ daria.m.adamczak@gmail.com; Tel.: +48-61-854-9146
}

Received: 30 September 2017; Accepted: 25 October 2017; Published: 27 October 2017

\begin{abstract}
Cardiovascular diseases are the leading cause of mortality worldwide. Therefore, a better understanding of their pathomechanisms and the subsequent implementation of optimal prophylactic and therapeutic strategies are of utmost importance. A growing body of evidence states that low-grade inflammation is a common feature for most of the cardiovascular diseases in which the contributing factors are the activation of toll-like receptors (TLRs) and vitamin D deficiency. In this article, available data concerning the association of cardiovascular diseases with TLRs and vitamin $\mathrm{D}$ status are reviewed, followed by a discussion of new possible approaches to cardiovascular disease management.
\end{abstract}

Keywords: toll-like receptors; vitamin D; cardiovascular diseases; atherosclerosis; inflammation

\section{Toll-Like Receptors}

Toll-like receptors (TLRs) are members of the pattern-recognition receptors (PRRs) family and play a key role in the phylogenetically ancient innate immune system. Due to PRRs, the eukaryotic organism is able to discriminate between self and non-self antigens [1-3]. There are 13 TLRs in mammalian species, and each one perceives a specific ligand, with the exception of TLR11 that is not functional, while TLR12 and -13 are not expressed in humans [4]. TLRs are cell surface and intracellular (TLR3, -7, -8 and -9) single, membrane-spanning, non-catalytic receptors expressed mainly on sentinel cells such as macrophages and dendritic cells. Their name derives from homology to the Drosophila Toll molecule - an important component of dorsal-ventral patterning and antifungal defense.

TLRs recognize conserved microbial structures called PAMPs (pathogen-associated molecular patterns) as well as host biomolecules associated with cell damage or necrosis called DAMPs (danger-associated molecular patterns) and induce an immune response. They utilize leucine-rich-repeat motifs (similar to interleukin (IL)-1) to bind the ligands and a shared cytoplasmic domain to recruit the following adaptors for downstream signaling: MyD88 (myeloid differentiation factor 88), TRIF (TIR-domain-containing adaptor inducing interferon- $\beta$ ), TIRAP (TIR domain-containing adaptor protein) and/or TRAM (TRIF-related adaptor molecule) [5,6]. The crucial end-point of the cascade reactions is unmasking the nuclear localization domain of NF- $\mathrm{kB}$ (nuclear factor $\kappa$-light-chain-enhancer of activated B cells), which after its translocation into the nucleus, activates multiple pro-inflammatory genes $[7,8]$. TLR stimulation via PAMPs (e.g., microbial nucleic acids, bacterial lipoglycans, carbohydrates and peptides, protozoan glycosylphosphatidylinositol anchors, fungal glucans and chitin) or DAMPs (e.g., heat-shock proteins, HMGB1 (high-mobility group box 1), uric acid, ATP and DNA) leads to synthesis of type I interferons via the TRIF-dependent pathway and pro-inflammatory cytokines via the MyD88-dependent pathway, as well as the maturation of dendritic cells and even in some cases an induction of the adaptive immune system [9-11]. Additionally, TLRs play a role in the regulation of immune responses (suppression and contrasupression) by direct and indirect influence on the function of $\mathrm{CD}^{+} \mathrm{CD} 25^{+}$(cluster of differentiation) T regulatory cells (Tregs). 
Finally, mounting evidence demonstrates that TLRs and the innate immune system are involved in the pathogenesis of disorders associated with chronic inflammation such as diabetes mellitus, asthma, Crohn's disease, systemic lupus erythematosus, cancer and cardiovascular diseases, which suggests new possible therapeutic targets $[12,13]$.

\subsection{Toll-Like Receptors and Cardiovascular Diseases}

Apart from being expressed in immune cells, TLRs are expressed in other cells found in the epithelium, endothelium, as well as adipocytes and those of the cardiovascular system [1,14-16]. Messenger RNA for TLR1-10 has been detected in the human heart [17]. Nevertheless, the role of the innate immune system in the pathogenesis of cardiovascular diseases has been discovered only recently. The most investigated receptor in this area is TLR4. Aggregated data suggest that short-term activation of TLRs has a cytoprotective effect on the cardiovascular system, whereas prolonged or excessive activation of TLRs induces chronic low-grade inflammation, which leads to endothelial dysfunction, increased cell death, adverse cardiac remodeling and subsequently coronary and cerebrovascular atherosclerosis, heart failure, septic cardiomyopathy, viral myocarditis, valvular diseases, thrombosis and/or hypertension $[4,11,14,15,18,19]$. Furthermore, cardiovascular risk factors such as diabetes, obesity and insulin resistance, are also associated with a low-grade inflammation that mimics the activation of innate immunity associated with metabolic, environmental, and genetic factors [20]. Taking into account that cardiovascular diseases are the leading cause of mortality worldwide (17.6 million deaths in 2016 with 14.5\% rise from 2006 to 2016), thorough knowledge of the pathomechanisms of TLRs is very important [21].

\subsection{Coronary and Cerebrovascular Atherosclerosis}

There is a growing body of evidence that innate immune mechanisms may initiate and accelerate atherosclerosis [22]. Normal arteries show very low levels of all TLRs, with the exception of TLR4, found at a relatively higher level [23]. However, in atherosclerotic lesions, TLR1, $-2,-4$ and -5 have been identified in abundance. It is important to note that TLR4 is concentrated and upregulated (likely by oxidized low-density lipoproteins) in areas of atherosclerotic plaques most vulnerable to rupture. TLR4 also contributes to intimal foam cell accumulation as well as TLR2, although to a lesser extent. Additionally, TLR signaling induces leukocyte recruitment and enhances matrix metalloproteinase expression within atherosclerotic lesions, therefore weakening plaque caps [4,24-27]. Furthermore, hyaluronic acid, a constituent of the extracellular matrix of eroded lesions, serves as a DAMP of TLR2, which is involved in promoting endothelial cell apoptosis [28,29]. Studies from the early 2000s emphasized the key role of MyD88 in atherosclerosis. It was hypothesized that its inactivation led to reduced macrophage recruitment to the artery wall and diminished plaque formation. However, recent data suggest that the impact of MyD88 on CD11c ${ }^{+}$dendritic cells $\left(\mathrm{CD} 11 \mathrm{c}^{+} \mathrm{DCs}\right)$ is significant. CD11 is a transmembrane protein found on immune cells, which induces cellular activation and helps trigger neutrophil oxidative burst. The dominant effect of MyD88 signaling in $\mathrm{CD} 11 \mathrm{c}^{+} \mathrm{DC}$ is to promote their maturation and the development of atheroprotective Tregs as well as proatherogenic T effector (Teff) cells. Tregs exert their atheroprotective action via suppression of Teff cells and inflammatory macrophages, and they inhibit monocyte recruitment by decreasing MCP-1 (monocyte chemotactic protein-1) production, a proces dependent on TGF- $\beta$ (transforming growth factor $\beta$ ) [30-32]. However, one study revealed that in the absence of MyD88 signaling in CD11 $\mathrm{c}^{+} \mathrm{DCs}$, the loss of Tregs response surpassed the loss of $\mathrm{T}$ effector cell activation [33]. On the contrary, another study showed that fewer Tregs are found in atherogenic $A p o E^{-/-}$(apolipoprotein E knockout) mice comparing to wild-type controls, suggesting an imbalance between Tregs and Teffs in atherogenesis. In addition, MyD88 signaling in $\mathrm{CD}^{+} \mathrm{T}$ cells is required to overcome suppression by Tregs. Moreover, $\mathrm{CD}^{+} \mathrm{T}$ cell anergy generates Tregs precursors [34-36]. Based on this evidence, it can be concluded that the impact of TLRs on atherosclerosis is a much more complicated issue than previously thought. Furthermore, TLR3 that signals via TRIF and is MyD88-independent unexpectedly 
plays a protective role in plaque formation [37]. It may stem from the ability of TLR3 to induce the expression of cytoprotective and anti-inflammatory glycoprotein clusterin/apolipoprotein J to prevent the progression of atherosclerosis [38].

\subsection{Acute Coronary Syndrome}

Besides promoting atherosclerosis, TLR-induced inflammation may influence atherosclerotic plaque stability and contribute to the development of acute coronary syndromes in patients with coronary artery disease. Microbial products within the plaques may promote its growth and rupture by activating inflammatory cells [39]. Recent studies revealed that median TLR2 and -4 expressions on platelets and plaque debris were greater in patients with acute coronary syndrome compared to those with stable angina pectoris [40,41]. Smaller infarctions and less inflammation has also been observed in mice subjected to myocardial ischemia-reperfusion and treated with TLR2 or TLR4 antagonists (anti-TLR2 antibody and Eritoran, respectively) [42,43]. In addition, the same effect occurred in TLR4-deficient mice [44]. Increased activation of TLR2 and -4 was observed also in human circulating monocytes during acute coronary syndrome. The extent of TLR activation preceded massive troponin $\mathrm{T}$ release and correlated with the ischemic area measured by cardiac magnetic resonance. On the other hand, TLR4 signaling plays a potent role in cardiac protection against ischemia-reperfusion injury via inducible nitric oxide synthase (iNOS) [45].

\subsection{Stroke}

Brain damage caused by stroke may be exacerbated due to acute inflammation triggered by cerebral ischemia [46]. The regulation of post-stroke inflammation involves vascular effects, chemotaxis, cellular responses and necrosis [47]. TLRs are expressed on endogenous neural cells along with infiltrating immune cells that access lesions due to damaged blood-brain barrier. The role of TLRs in cerebrovascular injury can be classified into two categories. The first category is post-ischemic TLR activation that mediates neuroinflammation and neurodegeneration (TLR2, $-4,-5,-7,-8$, and -9). The second category is pre-ischemic TLR stimulation, which is neuroprotective and preconditions brain to oxygen and nutrient deprivation (TLR2, -3, -4, -7, and -9) [48-54]. Recent studies revealed that TLR2and TLR4-deficient mice had significantly less neurologic deficit following induced cerebral ischemia compared to controls $[55,56]$. On the other hand, preconditioning with a TLR2 ligand protected the brain from ischemia-reperfusion injury, possibly through a TLR2/PI3K/protein kinase B-dependent mechanism [57,58]. Additionally, treatment with TLR4 antagonist reduced neuroinflammation and neurologic deficits after intracerebral hemorrhage [59]. Surprisingly, TLR4-deficient mice exhibited worse outcomes versus controls after preconditioning [60]. The explanation of this phenomenon may be the ability of TLR4 to promote neurogenesis after stroke [61].

\subsection{Thrombosis}

Thrombosis is the formation of a blood clot inside a blood vessel, which leads to ischemia of the obstructed area. Platelets play a key role in this process. Furthermore, all 10 TLRs are found in human thrombocytes and their activation leads to platelet adhesion, aggregation, and production of mixed platelet-leukocyte formations, secretion of cytokines and chemokines, as well as reactive oxygen species (ROS) and thrombin generation $[62,63]$. Therefore, activation of the innate immune system, either by pathogens or by tissue damage, can lead to thrombosis and consecutive coronary events.

\subsection{Heart Failure}

Congestive heart failure may occur due to many pathological conditions such as coronary artery disease, hypertension or valvular dysfunction. The compensatory, but otherwise maladaptive remodeling process following a myocardial infarction leads to diastolic impairment and further deterioration of cardiac function. TLRs are involved in heart failure pathogenesis and myocardial remodeling [19]. It has been proven that TLR4 expression is increased in patients with advanced 
heart failure [64]. TLR2, $-4,-5$ and -9 signaling results in a strong inflammatory response via NF- $\mathrm{KB}$ and decreased contractility in human and murine cardiomyocytes [65-67]. TLR4 triggers not only an inflammatory response, but also extracellular matrix degradation, which contributes to left ventricular remodeling. Its deficiency has an opposite effect, at least in murine models [68].

\subsection{Valvular Heart Disease}

The role of TLRs in valvular disease is not very well known, however a few studies revealed a link between innate immunity and aortic valve calcification. TLR2 and -4 increase gene expression of osteogenic factors, such as BMP-2 (bone morphogenetic protein-2) and Runx2 (Runt-related transcription factor 2) $[69,70]$. Although more research is needed to fully understand the role of TLRs in valvular heart disease, a small study showed that plasma and tissue TNF- $\alpha$ (tumor necrosis factor alpha) and IL-6 (interleukin 6) levels correlated with the calcification of human aortic valve, which may be a result of TLR2 and -4 upregulation [71].

\subsection{Arrhythmias}

Arrhythmias are another serious cardiovascular problem affecting many people worldwide with increasing mortality. The latest data suggest that TLR4 activation promotes cardiac arrhythmias by decreasing the transient outward potassium current (Ito) through an interferon regulatory factor 3 (IFN3)-dependent and MyD88-independent pathway [72]. Furthermore, research in mice models revealed that TLR2 signaling triggers fatal arrhythmias upon myocardial ischemia-reperfusion. Absence of TLR2 improved survival toward 100\% [73].

\subsection{Hypertension}

The pathogenesis of hypertension is a complex issue, considering the involvement of many factors such as the kidneys, autonomic nervous system and arteries as well as the uncontrolled activation of immune system and inflammation. However, TLRs have been suggested as the unifying factors in these processes [74,75]. TLR4 contributes to the etiology of vascular dysfunction and hypertension in various experimental models such as a spontaneously hypertensive rat (SHR) and rats with angiotensin II-induced hypertension [76,77]. Some authors even recognize angiotensin II as a DAMP for TLR4, as well as for TLR7-9 [78,79]. TLR4 also plays a role in paraventricular nucleus-mediated autonomic dysfunction in those animal models [80,81]. On the other hand, TLR5 has not been directly linked with high blood pressure, but it contributes greatly to metabolic syndrome [82]. Furthermore, TLR9 inhibition in SHR led to a decrease in blood pressure, whereas its activation induced vascular dysfunction and increased blood pressure in normotensive rats [79,83]. Finally, it was observed that TLR9 is a negative regulator of cardiac vagal tone and baroreflex function $[84,85]$.

\subsection{Cardiac Involvement in Infectious Diseases}

Although further research is required to determine the full spectrum of endogenous molecules leading to myocardial damage in sepsis, recent studies have shown that mice deficient in TLR4 or IRAK1 (interleukin-1 receptor-associated kinase 1) are protected from mortality induced by lipopolysaccharide (LPS) and cardiac dysfunction [85,86]. Activation of TLR4 by LPS results in production of TNF (tumor necrosis factor), interleukin $1 \beta$ (IL-1 $\beta$ ), NO (nitric oxide) and NOS2 (nitric oxide synthase 2) [87]. Additionally, TLR2 and -9 knockout mice are protected from Staphylococcus aureus and synthetic bacterial DNA, respectively, thus proving multiple TLRs are involved in septic cardiomyopathy pathogenesis $[67,88]$.

Viral infections can activate innate immune signaling within the heart through Myd88-dependent (TLR7-9) and MyD88-independent pathways (TLR3). In TLR3 knockout mice infected with encephalomyocarditis virus (EMCV) and Coxsackievirus group B serotype 3 (CVB3), an earlier mortality was seen when compared to wild-type mice. This has been associated with increased viral replication and myocardial injury $[89,90]$. These results suggest that TLR3-mediated recognition 
of a viral infection, with subsequent activation of antiviral mechanisms (e.g., type I interferon response) may be crucial to minimize viral replication in the heart. Similar outcomes were seen in TLR9 deficient and MyD88 deficient mice infected with cytomegalovirus (CMV) [91]. On the other hand, studies performed in CVB3 infected MyD88 deficient mice showed improved survival in the study group when compared to the control one. Moreover, pathological examination of the hearts revealed a significant decrease in CVB3 titers and cardiac inflammation in those mice [92]. The discrepancy regarding the abovementioned findings is hard to explain, but may be related to the MyD88-independent antiviral mechanisms that have not yet been discovered. Nevertheless, the reviewed data suggest that TLR-mediated viral mechanisms in the heart play an important role in the pathogenesis of myocarditis.

\section{Vitamin D}

Vitamin D is a group of fat-soluble secosteroids. The most important compounds in humans are vitamin $\mathrm{D}_{3}$ (cholecarciferol) and vitamin $\mathrm{D}_{2}$ (ergocalciferol). They play an essential role in calcium homeostasis and bone metabolism. Vitamin $\mathrm{D}_{2}$ and $\mathrm{D}_{3}$ can be ingested from diet, although only few foods, such as fatty fish liver and egg yolks contain them. However, the major natural source of vitamin $\mathrm{D}_{3}$ is dermal synthesis from sun exposure, especially UVB radiation [93,94]. Vitamin $\mathrm{D}$ itself is a prohormone, that is enzymatically converted in the liver to the major circulating form 25-hydroxyvitamin D (25(OH)D; calcidiol). Afterwards, the resultant compound is transformed in the renal proximal tubules (and at least 10 other tissues) to the most active form 1,25-dihydroxyvitamin $\mathrm{D}$ $(1,25(\mathrm{OH})(2) \mathrm{D}$; calcitriol). 25-hydroxyvitamin $\mathrm{D}$ is less than $1 \%$ as potent as 1,25 -dihydroxyvitamin $\mathrm{D}$, but, on the other hand, it has a half-life of 2-3 weeks compared with 4-6 hours for its active form. Therefore, 25(OH)D is used as a maker of vitamin D status in the organism. 1,25(OH)(2)D activates its cellular receptor VDR (vitamin D receptor), a member of the superfamily of hormone-activated nuclear receptors regulating eukaryotic gene expression. VDR acts as a transcription factor that binds to specific DNA sequences, HREs (hormone response elements), in target gene promoters [95]. It is nearly universally expressed in all nucleated cells and approximately $3 \%$ of the human genome is under the control of 1,25(OH)(2)D [96].

Apart from the well-known role of vitamin $\mathrm{D}$, research during the past three decades has revealed a diverse range of its biological actions such as induction of cell differentiation, inhibition of cell growth, immunomodulation, and control of other hormonal systems [94]. The importance of vitamin D in extraskeletal health is evident due to the diverse pathology associated with vitamin D deficiency. There are two conflicting statements concerning vitamin D optimal status. The first one requires serum $25(\mathrm{OH}) \mathrm{D}$ at $20 \mathrm{ng} / \mathrm{mL}$, at least, to regulate calcium and bone homeostasis. The second one demands higher concentrations to maintain extraskeletal health. Some authors favor levels $20-40 \mathrm{ng} / \mathrm{mL}$ (50 to $100 \mathrm{nmol} / \mathrm{L}$ ), whereas other experts support levels $30-50 \mathrm{ng} / \mathrm{mL}$ (75 to $125 \mathrm{nmol} / \mathrm{L}$ ), since concentrations $>150 \mathrm{ng} / \mathrm{mL}$ are associated with hypercalcemia and hyperphosphatemia [97-100]. Vitamin D deficiency is a major public health problem worldwide in all age groups, especially in infants, children and adolescents. In the National Health and Nutrition Examination Survey (NHANES) 2005 to $2006,41.6 \%$ of adult participants ( $\geq 20$ years) had $25(\mathrm{OH}) \mathrm{D}$ levels $<20 \mathrm{ng} / \mathrm{mL}$. Surprisingly, low vitamin D levels are a serious issue even in sunny regions, particularly in the Middle East [101-103]. Vitamin D deficiency is linked to not only rickets and osteoporosis, but also cancer, infectious, autoimmune, respiratory and finally cardiovascular diseases [104,105].

\subsection{Vitamin D and Cardiovascular Diseases}

A number of observational studies reported an inverse association between 25(OH)D levels and risk of cardiovascular diseases [106-108]. Vitamin D deficiency contributes to the development of cardiovascular diseases both directly and indirectly. VDRs are expressed in many tissues, including cardiomyocytes, vascular smooth muscle cells and endothelium. Calcitriol regulates the RAAS (renin-angiotensin system), suppresses vascular smooth muscle cells proliferation, improves insulin resistance and endothelial cell-dependent vasodilation, whilst also inhibiting myocardial 
cell hypertrophy, exertion of anticoagulant along with antifibrotic activity and finally modulates macrophage activity and cytokine generation [109]. Moreover, low levels of 25(OH)D are associated with cardiovascular risk factors, such as diabetes, obesity and dyslipidemia [110]. Elderly people are at risk for vitamin D deficiency as a result of decreased cutaneous synthesis and dietary intake. Epidemiologic studies indicate an association between low levels of vitamin D and diseases associated with aging, e.g., cardiovascular diseases [111]. Since screening and treatment of vitamin D deficiency are relatively easy, research concerning its connection to cardiovascular diseases, has important implications for patient care, as well as health policy [112]. However, there is a discrepancy between findings from observational studies and randomized trials on association between vitamin $\mathrm{D}$ and risk of cardiovascular diseases. Nevertheless, data from randomized controlled trials are characterized by a high degree of heterogeneity concerning optimal 25(OH)D concentrations, and only few of them specifically investigated effects in a population with low vitamin D levels $[113,114]$.

\subsection{Coronary and Cerebrovascular Atherosclerosis}

Vitamin D deficiency is associated with endothelial dysfunction, inflammation, and vascular calcification-phenomena involved in pathogenesis of atherosclerosis [115-117]. The endothelial cells express VDRs and have an ability to synthesize calcitriol [118]. That strengthens the hypothesis that vitamin D modulates the endothelial function on autocrine and intracrine processes [119]. The protective effects of vitamin D on endothelium are exerted through genomic and nongenomic mechanisms. It suppresses the NADPH (reduced nicotinamide adenine dinucleotide phosphate) oxidase subunit p22(phox) and is a direct transcriptional regulator of endothelial NO synthase (eNOS), therefore increasing NO production, whilst decreasing ROS production [120-122]. VDR mutant mice are characterized by a lower bioavailability of the vasodilator nitric oxide, which leads to endothelial dysfunction, increased arterial stiffness, increased aortic impedance, structural remodeling of the aorta, and subsequently impaired systolic and diastolic heart function [123]. Calcitirol inhibits also the expression of interleukins 6 and 8, as well as RANTES (regulated on activation, normal T cell expressed, and secreted), ICAM-1 (intercellular adhesion molecule-1), PECAM-1 (platelet-endothelial cell adhesion molecule-1), VCAM-1 (vascular cell adhesion molecule-1), RAGE (receptor of advanced glycation end products) and E-selectin through NF-KB-mediated pathway [124-128]. Furthermore, vitamin D reduces the levels of prostaglandins by repressing the expression of COX-2 (cyclooxygenase-2) and upregulation the expression of an enzyme initiating prostaglandin catabolism, namely 15PGDH (15-hydroxyprostaglandin dehydrogenase) $[129,130]$. Finally, calcitriol reduces calcium influx into the endothelial cells and hence decreases the production of EDCFs (endothelium-derived contracting factors). It also directly downregulates the expression of COX-1 (cyclooxygenase-1), which is a major source of EDCFs [131-133]. Another interesting study revealed that oral administration of calcitirol decreases atherosclerosis in mice by inducing Tregs and immature dendritic cells with tolerogenic functions $[134,135]$. On the other hand, some researchers claim that prolonged or high dose vitamin D supplementation, unless needed to correct the deficiency, may even be immunologically harmful by downregulating Th1 immune responses and indirectly upregulating Th2 immune activation with potential disadvantageous metabolic and cardiovascular effects [136]. Nevertheless, patients with coronary artery disease and lower vitamin D concentrations tend to have higher troponin I levels [137].

\subsection{Acute Coronary Syndrome}

Vitamin D deficiency was also observed in acute coronary syndromes and was associated with a less favorable outcome. In a study of patients with myocardial infarctions, those who were in the lowest quartile of $25(\mathrm{OH}) \mathrm{D}$ levels had a higher risk for several in-hospital complications, including death, as well as one-year mortality. There were no observed differences in $25(\mathrm{OH}) \mathrm{D}$ concentrations between patients with ST-elevation myocardial infarction (STEMI) and non-ST-elevation myocardial infarction (NSTEMI) [138]. Another study supported those observations and indicated that vitamin D was independently related to mortality at levels below the population median [139]. In addition, 
the left ventricular function was more severely compromised in deficient patients [140]. Furthermore, the diabetic patients with $25(\mathrm{OH}) \mathrm{D}$ deficiency had more extensive coronary lesions [141]. From the molecular point of view, in vitro experiments in human endothelial cells showed that calcitriol decreased the expression of membrane type 1 matrix metalloproteinase and platelet activation through a reduction of the CD62p platelet adhesion molecule what may have therapeutic effects against destabilization of atherosclerotic plaques and thrombosis [128].

\subsection{Stroke}

Epidemiological studies have largely, however inconsistently, shown that vitamin D deficiency is a risk factor for strokes. It exerts neuroprotective, neuromuscular and osteoprotective effects which may reduce cognitive and functional impairments in post-stroke patients [142]. The latest research revealed that patients with ischemic stroke and vitamin D deficiency who received a single dose of 6 lac IU of Cholecalciferol Intramascular (IM) injection, had a significant improvement in the stroke outcome after three months of follow-up (assessed by Scandinavian Stroke Scale) compared to the control group [143].

\subsection{Thrombosis}

Although data concerning the relationship between vitamin $\mathrm{D}$ and thrombosis are very scarce, there is some evidence of low $25(\mathrm{OH}) \mathrm{D}$ levels associated with venous thromboembolism $[144,145]$.

\subsection{Heart Failure}

Heart failure is associated with upregulation of the RAAS and sympathetic nervous system, which leads to alterations in $\beta$-adrenergic signaling, impaired mobilization of intracellular calcium and subsequently cardiomyocyte fibrosis, hypertrophy and interstitial collagen accumulation. As a result, negative ventricular remodeling occurs [146-148]. Available data indicate that the majority of congestive heart failure (CHF) patients have vitamin D deficiency [149]. Factors predisposing those patients to hypovitaminosis D include nutritional deficiency, decreased skin production, reduced intestinal absorption and hepatorenal disease [150]. Low vitamin D levels can in turn exacerbate $\mathrm{CHF}$ and lead to secondary hyperparathyroidism, which independently contributes to abnormalities in calcium homeostasis and subsequently left ventricular hypertrophy and diastolic dysfunction [151]. On the other hand, calcitriol decreases inflammation and downregulates pro-fibrotic signaling pathways by reducing TGF- $\beta 1$ levels, stress fiber formation, and $\alpha$-smooth muscle actin expression [152-154]. Moreover, patients with heart failure, who supplemented vitamin D, had higher serum concentrations of the anti-inflammatory cytokine IL-10 than the control group [155]. Some authors even postulate, that vitamin D-dependent mechanisms activating calcium channels may become a novel target therapy in heart failure patients [156]. What is interesting, in a population-based sample of mainly vitamin D-sufficient subjects without heart disease, the geometry of left ventricle was most favorable at intermediate 25(OH)D concentrations, namely 30-37 ng/mL [157].

\subsection{Valvular Heart Disease}

There are only few observational data concerning the relationship between hypovitaminosis $\mathrm{D}$ and valvular heart disease. On the other hand, aortic stenosis is the most common valvular heart disease in the developed countries and affects $2 \%$ people above 65 years old, while another $25-30 \%$ have aortic sclerosis. Since the mortality rate at 10 years in symptomatic patients is $90 \%$, it is a serious medical problem [158-160]. Although there is currently no medical therapy that can prevent the progression of aortic stenosis, recent data highlight its possible association with bone metabolism. In patients with normal vitamin D levels, progression of the disease is associated with bone resorptive balance, whereas in patients with hypovitaminosis D secondary hyperparathyroidism plays a role [161]. Furthermore, in calcific aortic valve disease, the early lesion is similar to atherosclerotic plaque, but later calcification prevails. In patients with coronary artery disease, higher serum iPTH (intact parathyroid hormone) with lower vitamin D levels are independently correlated with calcific aortic stenosis [162]. Another 
study revealed a link between vitamin D deficiency, secondary parathyroidism, oxidative stress and aortic as well as mitral valve regurgitation [163].

\subsection{Arrhythmias}

In the pathogenesis of atrial fibrillation (AF), intra- and interatrial electromechanical delay, abnormalities in left atrial mechanical function, as well as myocardial fibrosis all play a role. Since vitamin D downregulates the production of ROS and activity of RAAS, its beneficial impact on AF has been hypothesized. However, the mechanistic and observational studies revealed conflicting evidence. Most of the studies, including the Rotterdam Study of 3.395 participants conducted for 12 years, do not support association of vitamin D with AF. Another research study revealed that hypovitaminosis D modestly increases the risk of $A F$ [164-166]. In patients after coronary artery bypass surgery (CABG), the relationship between POAF (postoperative atrial fibrillation) with vitamin D deficiency is even more contradictory, although the significant negative correlation between $25(\mathrm{OH}) \mathrm{D}$ levels and left atrial diameter has been observed $[167,168]$. On the other hand, low plasma concentration of vitamin $\mathrm{D}$ was strongly associated with AF in patients with chronic CHF [169].

Although AF was the most investigated arrhythmia in context of vitamin D deficiency, the effectiveness of $\beta$-blocker treatment for premature ventricular complexes (PVCs) in patients with chronic kidney disease, was higher in subjects with a normal range of $25(\mathrm{OH}) \mathrm{D}$ in comparison to patients with deficiency or insufficiency [170].

\subsection{Hypertension}

The antihypertensive effects of vitamin D include suppression of RAAS, decreasing PTH (parathyroid hormone) levels, increasing urinary sodium excretion, as well as renoprotective, anti-inflammatory and vasculoprotective properties. Disruption of the VDR gene leads to an elevated renin production, left ventricular hypertrophy, and elevated blood pressure. Therefore, vitamin D deficiency was proposed as an independent risk factor for idiopathic arterial hypertension. Moreover, meta-analyses of randomized controlled trials showed that supplementation reduces systolic blood pressure by 2-6 $\mathrm{mmHg}$ [171-176]. Another meta-analysis of eight unique prospective cohorts (aggregated data of 283.537 subjects and 55.816 hypertension cases) has shown $30 \%$ reduced risk of hypertension with increasing vitamin D levels [177]. National Health and Nutrition Examination Survey (NHANES III) and Nurses' Health study II were also favorable for vitamin D $[178,179]$. On the other hand, the largest randomized trial evaluating the effect of vitamin D supplementation on hypertension - the Women's Health Initiative Calcium/vitamin D Trial of 36.282 postmenopausal women, along with Multi-Ethnic Study of Atherosclerosis Trial did not support the beneficial effect of vitamin D [180,181].

\subsection{Cardiac Involvement in Infectious Diseases}

Patients with sepsis have decreased vitamin D binding-protein (DBP) levels, which exacerbate the vitamin D deficiency. Furthermore, hypovitaminosis D is associated with increased risk of blood culture positivity [182]. The latest evidence has shown also that treatment of severely vitamin D-deficient, critically ill patients in the intensive care unit, who then receive high doses of vitamin $\mathrm{D}$, may improve mortality [183]. In animal models of sepsis associated with a disseminated intravascular coagulation, administration of calcitriol resulted in improvement of blood coagulation parameters. In vitro studies revealed also that vitamin D modulates levels of the systemic inflammatory cytokines, such as TNF- $\alpha$ and IL-6, as well as inhibits the LPS-induced activation and vasodilation of vascular endothelium. It also enhances the induction of the antimicrobial peptides on mucosal and epithelial surfaces- $\beta$-defensin and cathelicidin — which have been described as the first line of defense against bacterial and viral pathogens [184]. Another study concerning mice injected intraperitoneally with Coxsackievirus B3 revealed significantly increased expression of VDR in myocardium in the experimental group. Moreover, the changes in the pathological score of the myocardium positively 
correlated with the changes in the expression of VDR. However, administration of vitamin D in those mice as a next step of the study, could reveal a clinical value of calcitriol [185].

\section{Toll-Like Receptors and Vitamin D}

\subsection{The Interplay between TLRs and Vitamin D in Relation to Innate and Adaptive Immune System}

The effects of TLRs and vitamin D on the immune system are contradictory in most cases. Data concerning their impact on the innate and adaptive immune system are summarized in Figure 1 [186-198]. Although the effects of TLRs and vitamin D seem to be antagonistic, they produce synergistic effects during infectious diseases. On the other hand, a negative correlation between TLRs expression and $25(\mathrm{OH}) \mathrm{D}$ levels has been observed in many studies, especially in the diseases where inflammation plays a pivotal role, for example in diabetes mellitus type 1 or Behçet's disease. Furthermore, both vitamin D supplementation, as well as exposition of peripheral blood mononuclear cells (PBMCs) to vitamin D ex vivo, led to downregulation of TLRs' expression and decrease of pro-inflammatory cytokine production. These findings have potentially significant implications for the treatment of a variety of conditions, where achieving optimal vitamin D levels may help reduce inflammation [199-205].

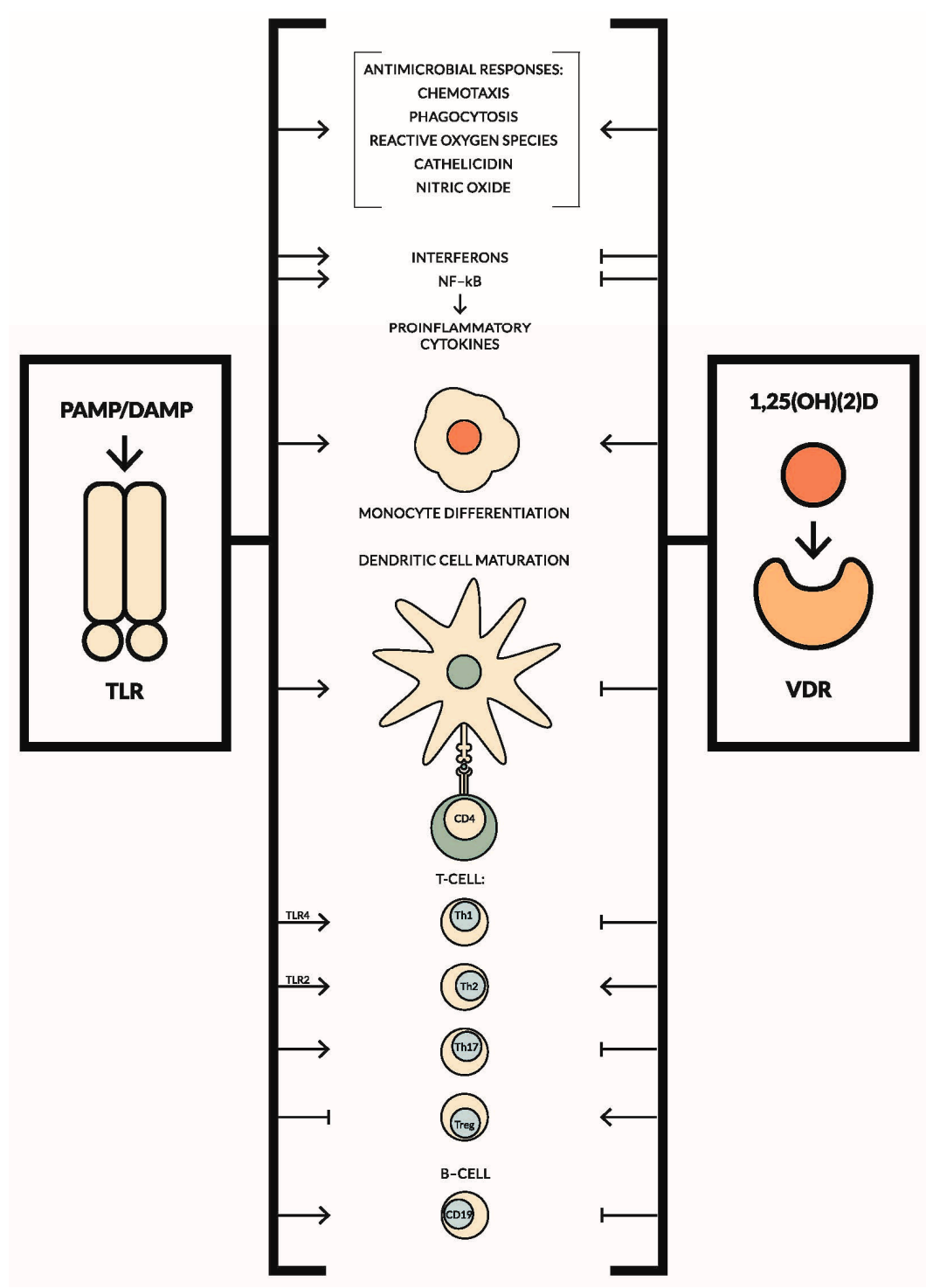

Figure 1. The role of toll-like receptors and vitamin D in innate and adaptive immune responses. 


\subsection{Toll-Like Receptors and Vitamin D in Cardiovascular Diseases}

As was presented previously, both TLRs and vitamin D play an important role in a wide spectrum of cardiovascular diseases. A possible therapeutic approach may be treatment with specific TLR antagonists, e.g., Eritoran, Tak242, statins (fluvastatin) and angiotensin receptor blockers (candesartan) [19,206-209]. However, the easiest and most cost efficient way to reduce the pro-inflammatory effect of TLRs seems to be vitamin D supplementation. Alternatively, adequate vitamin $25(\mathrm{OH}) \mathrm{D}$ concentrations can also be obtained through dietary vitamin $\mathrm{D}$ intake and skin exposure to solar UVB radiation, although not as effective as supplementation. The recommended daily oral doses for infants and the general population beyond infancy are $400 \mathrm{IU}$ and $800 \mathrm{IU}$, respectively. The upper tolerable intake level is considered to be $1000-4000 \mathrm{IU}$. For adults with hypovitaminosis D, the Endocrine Society recommends a daily vitamin D dose of 1500 to $2000 \mathrm{IU}$. It has been estimated that, for every $100 \mathrm{IU}$ of vitamin D ingested, the blood level of 25(OH)D increases by $1 \mathrm{ng} / \mathrm{mL}$. Daily doses of up to 10,000 IU are considered safe [104,210].

Randomized controlled trials concerning the therapeutic effects of vitamin D in cardiovascular diseases were not as appreciative as the observational studies due to the abovementioned reasons. Nevertheless, checking the vitamin D levels in all patients with cardiovascular disease and supplementation, if necessary, may be only beneficial.

\subsection{Emerging Role of Vitamin K2 in Cardiovascular Diseases and Its Relationship with TLRs and Vitamin D}

The latest research concerning this topic describes the emerging role of vitamin K2 (menaquinone) (especially subtypes MK-7, MK-8 and MK-9) in reducing cardiovascular risk. Vitamin K not only plays a vital role in blood coagulation, but also regulates tissue calcification, cell growth, bone formation and apoptosis. Vitamin $\mathrm{K}$ is needed for the carboxylation of proteins such as osteocalcin and matrix Gla protein, while vitamin D promotes their production. It leads to bone mineralization and inhibition of soft tissue calcification. As a result, optimal concentrations of vitamins D and K lower the risk of fractures and coronary heart disease [211-218]. To date, two intervention studies in healthy participants investigating the combined effect of vitamins $\mathrm{D}$ and $\mathrm{K}$ on vascular function and calcification have been conducted. The outcomes revealed maintained vessel wall characteristics of the carotid artery and less coronary artery calcium progression in the groups receiving dual supplementation $[219,220]$. Data concerning the relationship between TLRs and vitamin K are very scarce and no paper discussed the interplay among TLRs, and vitamins D and K so far. Nevertheless one study disclosed that menaquinone can suppress the expression of TLR2 and TLR4 as well as inhibit calcification of aortic intima and smooth muscle cells in $A p o E^{-/-}$mice [221]. Moreover, in vitro pretreatment of human monocyte-derived macrophages with menaquinone- 7 for $30 \mathrm{~h}$ and subsequent activation with TLR agonists resulted in inhibition of pro-inflammatory cytokine production [222]. Abovementioned outcomes allow concluding that vitamin D and K2 have a synergistic effect and dual supplementation may provide an added benefit for patients' bone and cardiovascular health.

\subsection{Summary}

To gain a deeper understanding of the role of TLRs and vitamin D in cardiovascular diseases, further experimental investigations as well as randomized controlled trials, most importantly with unified optimal $25(\mathrm{OH}) \mathrm{D}$ concentrations, are needed. It is significant not only in the treatment of individual patients, but also in prophylaxis, which may change the high mortality rates due to cardiovascular diseases currently observed.

Acknowledgments: I would like to thank Victoria Krzywicki and Peter Szafaryn from Poznan University of Medical Sciences, Center for Medical Education in English for their editorial assistance. I would also like to thank Adam Piasek, who designed a graphic.

Conflicts of Interest: The author declares no conflict of interest. 


\section{Abbreviations}

\begin{tabular}{|c|c|}
\hline TLRs & toll-like receptors \\
\hline PRR & pattern-recognition receptor \\
\hline PAMP & pathogen-associated molecular patterns \\
\hline DAMP & danger-associated molecular patterns \\
\hline TRIF & TIR-domain-containing adaptor inducing interferon- $\beta$ \\
\hline TIRAP & TIR domain-containing adaptor protein \\
\hline TRAM & TRIF-related adaptor molecule \\
\hline NF- $k B$ & nuclear factor $\mathrm{k}$-light-chain-enhancer of activated B cells \\
\hline HMGB1 & high-mobility group box 1 \\
\hline $\mathrm{CD}$ & cluster of differentiation \\
\hline Treg & $\mathrm{T}$ regulatory cell \\
\hline DC & dendritic cell \\
\hline Teff & T effector cell \\
\hline MCP-1 & monocyte chemotactic protein- 1 \\
\hline TGF- $\beta$ & transforming growth factor $\beta$ \\
\hline Apo $E^{-/-}$mice & apolipoprotein E knockout mice \\
\hline iNOS & inducible nitric oxide synthase \\
\hline ROS & reactive oxygen species \\
\hline BMP-2 & bone morphogenetic protein-2 \\
\hline Runx2 & Runt-related transcription factor 2 \\
\hline TNF- $\alpha$ & tumor necrosis factor alpha \\
\hline IL-6 & interleukin 6 \\
\hline Ito & potassium current \\
\hline IFN3 & interferon regulatory factor 3 \\
\hline SHR & spontaneously hypertensive rat \\
\hline IRAK1 & interleukin-1 receptor-associated kinase 1 \\
\hline LPS & Lipopolysaccharide \\
\hline TNF & tumor necrosis factor \\
\hline IL-1 $\beta$ & interleukin $1 \beta$ \\
\hline $\mathrm{NO}$ & nitric oxide \\
\hline NOS2 & nitric oxide synthase 2 \\
\hline EMCV & encephalomyocarditis virus \\
\hline CVB3 & coxsackievirus group B serotype 3 \\
\hline UVB radiation & ultraviolet $\mathrm{B}$ radiation \\
\hline $25(\mathrm{OH}) \mathrm{D}$ & 25-hydroxyvitamin $\mathrm{D}$, calcidiol \\
\hline $1,25(\mathrm{OH})(2) \mathrm{D}$ & 1,25-dihydroxyvitamin $\mathrm{D}$, calcitriol \\
\hline VDR & vitamin $\mathrm{D}$ receptor \\
\hline HREs & hormone response elements \\
\hline NHANES & national health and nutrition examination survey \\
\hline RAAS & renin-angiotensin system \\
\hline NADPH & reduced nicotinamide adenine dinucleotide phosphate \\
\hline eNOS & nitric oxide synthase \\
\hline RANTES & regulated on activation, normal $\mathrm{T}$ cell expressed, and secreted \\
\hline ICAM-1 & intercellular adhesion molecule-1 \\
\hline PECAM-1 & platelet-endothelial cell adhesion molecule-1 \\
\hline VCAM-1 & vascular cell adhesion molecule- 1 \\
\hline RAGE & receptor of advanced glycation end products \\
\hline COX-2 & cyclooxygenase-2 \\
\hline 15PGDH & 15-hydroxyprostaglandin dehydrogenase \\
\hline EDCFs & endothelium-derived contracting factors \\
\hline COX-1 & cyclooxygenase- 1 \\
\hline STEMI & ST-elevation myocardial infarction \\
\hline
\end{tabular}




$\begin{array}{ll}\text { NSTEMI } & \text { non-ST-elevation myocardial infarction } \\ \text { CHF } & \text { congestive heart failure } \\ \text { iPTH } & \text { intact parathyroid hormone } \\ \text { AF } & \text { atrial fibrillation } \\ \text { CABG } & \text { coronary artery bypass surgery } \\ \text { POAF } & \text { postoperative atrial fibrillation } \\ \text { PVC } & \text { premature ventricular complex } \\ \text { PTH } & \text { parathyroid hormone } \\ \text { DBP } & \text { vitamin D binding-protein } \\ \text { PBMC } & \text { peripheral blood mononuclear cell }\end{array}$

\section{References}

1. Majewska, M.; Szczepanik, M. The role of toll-like receptors (TLR) in innate and adaptive immune responses and their function in immune response regulation. Postep. Hig. Med. Doswiadczalnej 2006, 60, 52-63. [PubMed]

2. Schnare, M.; Rollinghoff, M.; Qureshi, S. Toll-like receptors: Sentinels of host defence against bacterial infection. Int. Arch. Allergy Immunol. 2006, 139, 75-85. [CrossRef] [PubMed]

3. Kumar, H.; Kawai, T.; Akira, S. Toll-like receptors and innate immunity. Biochem. Biophys. Res. Commun. 2009, 388, 621-625. [CrossRef] [PubMed]

4. Mann, D.L. The emerging role of innate immunity in the heart and vascular system: For whom the cell tolls. Circ. Res. 2011, 108, 1133-1145. [CrossRef] [PubMed]

5. Akira, S.; Takeda, K.; Kaisho, T. Toll-like receptors: Critical proteins linking innate and acquired immunity. Nat. Immunol. 2001, 2, 675-680. [CrossRef] [PubMed]

6. West, A.P.; Koblansky, A.A.; Ghosh, S. Recognition and signaling by toll-like receptors. Annu. Rev. Cell Dev. Biol. 2006, 22, 409-437. [CrossRef] [PubMed]

7. Cook, D.N.; Pisetsky, D.S.; Schwartz, D.A. Toll-like receptors in the pathogenesis of human disease. Nat. Immunol. 2004, 5, 975-979. [CrossRef] [PubMed]

8. Kawasaki, T.; Kawai, T. Toll-like receptor signaling pathways. Front. Immunol. 2014, 5. [CrossRef] [PubMed]

9. Tang, D.; Kang, R.; Coyne, C.B.; Zeh, H.J.; Lotze, M.T. PAMPs and DAMPs: Signal 0 s that spur autophagy and immunity. Immunol. Rev. 2012, 249, 158-175. [CrossRef] [PubMed]

10. Gazzinelli, R.T.; Denkers, E.Y. Protozoan encounters with toll-like receptor signalling pathways: Implications for host parasitism. Nat. Rev. Immunol. 2006, 6, 895-906. [CrossRef] [PubMed]

11. Goulopoulou, S.; McCarthy, C.G.; Webb, R.C. Toll-like receptors in the vascular system: Sensing the dangers within. Pharmacol. Rev. 2015, 68, 142-167. [CrossRef] [PubMed]

12. Jezierska, A.; Kolosova, I.A.; Verin, A.D. Toll like receptors signaling pathways as a target for therapeutic interventions. Curr. Signal Transduct. Ther. 2011, 6, 428-440. [CrossRef] [PubMed]

13. O'Neill, L.A.J.; Bryant, C.E.; Doyle, S.L. Therapeutic targeting of toll-like receptors for infectious and inflammatory diseases and cancer. Pharmacol. Rev. 2009, 61, 177-197. [CrossRef] [PubMed]

14. Frantz, S.; Ertl, G.; Bauersachs, J. Mechanisms of disease: Toll-like receptors in cardiovascular disease. Nat. Clin. Pract. Cardiovasc. Med. 2007, 4, 444-454. [CrossRef] [PubMed]

15. Vallejo, J.G. Role of toll-like receptors in cardiovascular diseases. Clin. Sci. 2011, 121, 1-10. [CrossRef] [PubMed]

16. Salvador, B.; Arranz, A.; Francisco, S.; Córdoba, L.; Punzón, C.; Llamas, M.Á.; Fresno, M. Modulation of endothelial function by toll like receptors. Pharmacol. Res. 2016, 108, 46-56. [CrossRef] [PubMed]

17. Nishimura, M.; Naito, S. Tissue-specific mRNA expression profiles of human toll-like receptors and related genes. Biol. Pharm. Bull. 2005, 28, 886-892. [CrossRef] [PubMed]

18. Dekleijn, D.; Pasterkamp, G. Toll-like receptors in cardiovascular diseases. Cardiovasc. Res. 2003, 60, $58-67$. [CrossRef]

19. Lin, E.; Freedman, J.E.; Beaulieu, L.M. Innate immunity and toll-like receptor antagonists: A potential role in the treatment of cardiovascular diseases. Cardiovasc. Ther. 2009, 27, 117-123. [CrossRef] [PubMed]

20. Spirig, R.; Tsui, J.; Shaw, S. The emerging role of TLR and innate immunity in cardiovascular disease. Cardiol. Res. Pract. 2012, 2012, 1-12. [CrossRef] [PubMed] 
21. Abajobir, A.A.; Abbafati, C.; Abbas, K.M.; Abd-Allah, F.; Abera, S.F.; Aboyans, V.; Adetokunboh, O.; Afshin, A.; Agrawal, A.; Ahmadi, A.; et al. Global, regional, and national age-sex specific mortality for 264 causes of death, 1980-2016: A systematic analysis for the global burden of disease study 2016. Lancet 2017, 390, 1151-1210. [CrossRef]

22. Libby, P.; Okamoto, Y.; Rocha, V.Z.; Folco, E. Inflammation in atherosclerosis: Transition from theory to practice. Circ. J. Off. J. Jpn. Circ. Soc. 2010, 74, 213-220. [CrossRef]

23. Edfeldt, K.; Swedenborg, J.; Hansson, G.K.; Yan, Z. Expression of toll-like receptors in human atherosclerotic lesions: A possible pathway for plaque activation. Circulation 2002, 105, 1158-1161. [PubMed]

24. Holloway, J.W.; Yang, I.A.; Ye, S. Variation in the toll-like receptor 4 gene and susceptibility to myocardial infarction. Pharmacogenet. Genom. 2005, 15, 15-21. [CrossRef]

25. Doherty, T.M.; Fisher, E.A.; Arditi, M. TLR signaling and trapped vascular dendritic cells in the development of atherosclerosis. Trends Immunol. 2006, 27, 222-227. [CrossRef] [PubMed]

26. Lin, J.; Kakkar, V.; Lu, X. Essential roles of toll-like receptors in atherosclerosis. Curr. Med. Chem. 2016, 23, 431-454. [CrossRef] [PubMed]

27. Higashimori, M.; Tatro, J.B.; Moore, K.J.; Mendelsohn, M.E.; Galper, J.B.; Beasley, D. Role of toll-like receptor 4 in intimal foam cell accumulation in apolipoprotein E-deficient mice. Arterioscler. Thromb. Vasc. Biol. 2011, 31, 50-57. [CrossRef] [PubMed]

28. Quillard, T.; Araújo, H.A.; Franck, G.; Shvartz, E.; Sukhova, G.; Libby, P. TLR2 and neutrophils potentiate endothelial stress, apoptosis and detachment: Implications for superficial erosion. Eur. Heart J. 2015, 36, 1394-1404. [CrossRef] [PubMed]

29. Crea, F.; Libby, P. Acute coronary syndromes: The way forward from mechanisms to precision treatment. Circulation 2017, 136, 1155-1166. [CrossRef] [PubMed]

30. Falck-Hansen, M.; Kassiteridi, C.; Monaco, C. Toll-like receptors in atherosclerosis. Int. J. Mol. Sci. 2013, 14, 14008-14823. [CrossRef] [PubMed]

31. Björkbacka, H.; Kunjathoor, V.V.; Moore, K.J.; Koehn, S.; Ordija, C.M.; Lee, M.A.; Means, T.; Halmen, K.; Luster, A.D.; Golenbock, D.T; et al. Reduced atherosclerosis in MyD88-null mice links elevated serum cholesterol levels to activation of innate immunity signaling pathways. Nat. Med. 2004, 10, 416-421. [CrossRef] [PubMed]

32. Michelsen, K.S.; Wong, M.H.; Shah, P.K.; Zhang, W.; Yano, J.; Doherty, T.M.; Akira, S.; Rajavashisth, T.B.; Arditi, M. Lack of toll-like receptor 4 or myeloid differentiation factor 88 reduces atherosclerosis and alters plaque phenotype in mice deficient in apolipoprotein E. Proc. Natl. Acad. Sci. USA 2004, 101, 10679-10684. [CrossRef] [PubMed]

33. Subramanian, M.; Thorp, E.; Hansson, G.K.; Tabas, I. Treg-mediated suppression of atherosclerosis requires MYD88 signaling in DCs. J. Clin. Investig. 2013, 123, 179-188. [CrossRef] [PubMed]

34. Kalekar, L.A.; Schmiel, S.E.; Nandiwada, S.L.; Lam, W.Y.; Barsness, L.O.; Zhang, N.; Stritesky, G.L.; Malhotra, D.; Pauken, K.E.; Linehan, J.L.; et al. CD4 ${ }^{+}$T cell anergy prevents autoimmunity and generates regulatory T cell precursors. Nat. Immunol. 2016, 17, 304-314. [CrossRef] [PubMed]

35. Schenten, D.; Nish, S.A.; Yu, S.; Yan, X.; Lee, H.K.; Brodsky, I.; Pasman, L.; Yordy, B.; Wunderlich, F.T.; Brüning, J.C.; et al. Signaling through the adaptor molecule MyD88 in CD4 ${ }^{+} \mathrm{T}$ cells is required to overcome suppression by regulatory T cells. Immunity 2014, 40, 78-90. [CrossRef] [PubMed]

36. Pastrana, J.L. Regulatory T cells and atherosclerosis. J. Clin. Exp. Cardiol. 2013. [CrossRef] [PubMed]

37. Cole, J.E.; Navin, T.J.; Cross, A.J.; Goddard, M.E.; Alexopoulou, L.; Mitra, A.T.; Davies, A.H.; Flavell, R.A.; Feldmann, M.; Monaco, C. Unexpected protective role for Toll-like receptor 3 in the arterial wall. Proc. Natl. Acad. Sci. USA 2011, 108, 2372-2377. [CrossRef] [PubMed]

38. Baiersdörfer, M.; Schwarz, M.; Seehafer, K.; Lehmann, C.; Heit, A.; Wagner, H.; Kirschning, C.J.; Koch-Brandt, C. Toll-like receptor 3 mediates expression of clusterin/apolipoprotein J in vascular smooth muscle cells stimulated with RNA released from necrotic cells. Exp. Cell Res. 2010, 316, 3489-3500. [CrossRef] [PubMed]

39. Libby, P.; Ridker, P.M.; Hansson, G.K. Inflammation in atherosclerosis. J. Am. Coll. Cardiol. 2009, 54, 2129-2138. [CrossRef] [PubMed]

40. Gurses, K.M.; Kocyigit, D.; Yalcin, M.U.; Canpinar, H.; Oto, M.A.; Ozer, N.; Tokgozoglu, L.; Guc, D.; Aytemir, K. Enhanced platelet toll-like receptor 2 and 4 expression in acute coronary syndrome and stable angina pectoris. Am. J. Cardiol. 2015, 116, 1666-1671. [CrossRef] [PubMed] 
41. Satoh, S.; Yada, R.; Inoue, H.; Omura, S.; Ejima, E.; Mori, T.; Takenaka, K.; Kawamura, N.; Numaguchi, K.; Mori, E.; et al. Toll-like receptor-4 is upregulated in plaque debris of patients with acute coronary syndrome more than toll-like receptor-2. Heart Vessels 2016, 31, 1-5. [CrossRef] [PubMed]

42. Arslan, F.; Smeets, M.B.; O’Neill, L.A.J.; Keogh, B.; McGuirk, P.; Timmers, L.; Tersteeg, C.; Hoefer, I.E.; Doevendans, P.A.; Pasterkamp, G.; et al. Myocardial ischemia/reperfusion injury is mediated by Leukocytic toll-like receptor- 2 and reduced by systemic administration of a novel anti-toll-like receptor-2 antibody. Circulation 2010, 121, 80-90. [CrossRef] [PubMed]

43. Shimamoto, A.; Chong, A.J.; Yada, M.; Shomura, S.; Takayama, H.; Fleisig, A.J.; Agnew, M.L.; Hampton, C.R.; Rothnie, C.L.; Spring, D.J.; et al. Inhibition of toll-like receptor 4 with eritoran attenuates myocardial ischemia-reperfusion injury. Circulation 2006, 114, I270-I274. [CrossRef] [PubMed]

44. Oyama, J.-I. Reduced myocardial ischemia-reperfusion injury in toll-like receptor 4-deficient mice. Circulation 2004, 109, 784-789. [CrossRef] [PubMed]

45. Wang, E.; Feng, Y.; Zhang, M.; Zou, L.; Li, Y.; Buys, E.S.; Huang, P.; Brouckaert, P.; Chao, W. Toll-like receptor 4 signaling confers cardiac protection against ischemic injury via inducible nitric oxide synthase- and soluble guanylate cyclase-dependent mechanisms. Anesthesiology 2011, 114, 603-613. [CrossRef] [PubMed]

46. Shichita, T.; Ito, M.; Yoshimura, A. Post-ischemic inflammation regulates neural damage and protection. Front. Cell. Neurosci. 2014, 8. [CrossRef] [PubMed]

47. Downes, C.E.; Crack, P.J. Neural injury following stroke: Are toll-like receptors the link between the immune system and the CNS? Neural injury and the immune system. Br. J. Pharmacol. 2010, 160, 1872-1888. [CrossRef] [PubMed]

48. Fadakar, K.; Dadkhahfar, S.; Esmaeili, A.; Rezaei, N. The role of toll-like receptors (TLRs) in stroke. Rev. Neurosci. 2014, 25. [CrossRef] [PubMed]

49. Qiao, H.; Zhang, X.; Zhu, C.; Dong, L.; Wang, L.; Zhang, X.; Xing, Y.; Wang, C.; Ji, Y.; Cao, X. Luteolin downregulates TLR4, TLR5, NF-KB and p-p38MAPK expression, upregulates the p-ERK expression, and protects rat brains against focal ischemia. Brain Res. 2012, 1448, 71-81. [CrossRef] [PubMed]

50. Zhang, X.; Ha, T.; Lu, C.; Lam, F.; Liu, L.; Schweitzer, J.; Kalbfleisch, J.; Kao, R.L.; Williams, D.L.; Li, C. Poly (I:C) therapy decreases cerebral ischaemia/reperfusion injury via TLR3-mediated prevention of Fas/FADD interaction. J. Cell. Mol. Med. 2015, 19, 555-565. [CrossRef] [PubMed]

51. Brea, D.; Sobrino, T.; Rodríguez-Yáñez, M.; Ramos-Cabrer, P.; Agulla, J.; Rodríguez-González, R.; Campos, F.; Blanco, M.; Castillo, J. Toll-like receptors 7 and 8 expression is associated with poor outcome and greater inflammatory response in acute ischemic stroke. Clin. Immunol. 2011, 139, 193-198. [CrossRef] [PubMed]

52. Zhang, J.; Fu, B.; Zhang, X.; Chen, L.; Zhang, L.; Zhao, X.; Bai, X.; Zhu, C.; Cui, L.; Wang, L. Neuroprotective effect of bicyclol in rat ischemic stroke: Down-regulates TLR4, TLR9, TRAF6, NF-kB, MMP-9 and up-regulates claudin-5 expression. Brain Res. 2013, 1528, 80-88. [CrossRef] [PubMed]

53. Ji, Y.; Zhou, Y.; Pan, J.; Li, X.; Wang, H.; Wang, Y. Temporal pattern of toll-like receptor 9 upregulation in neurons and glial cells following cerebral ischemia reperfusion in mice. Int. J. Neurosci. 2016, 126, 269-277. [CrossRef] [PubMed]

54. Stevens, S.L.; Ciesielski, T.M.; Marsh, B.J.; Yang, T.; Homen, D.S.; Boule, J.-L.; Lessov, N.S.; Simon, R.P.; Stenzel-Poore, M.P. Toll-Like receptor 9: A new target of ischemic preconditioning in the brain. J. Cereb. Blood Flow Metab. 2008, 28, 1040-1047. [CrossRef] [PubMed]

55. Tang, S.-C.; Arumugam, T.V.; Xu, X.; Cheng, A.; Mughal, M.R.; Jo, D.G.; Lathia, J.D.; Siler, D.A.; Chigurupati, S.; Ouyang, X.; et al. Pivotal role for neuronal toll-like receptors in ischemic brain injury and functional deficits. Proc. Natl. Acad. Sci. USA 2007, 104, 13798-13803. [CrossRef] [PubMed]

56. Cao, C.; Yang, Q.; Lv, F.; Cui, J.; Fu, H.; Wang, J. Reduced cerebral ischemia-reperfusion injury in toll-like receptor 4 deficient mice. Biochem. Biophys. Res. Commun. 2007, 353, 509-514. [CrossRef] [PubMed]

57. Hua, F.; Ma, J.; Ha, T.; Kelley, J.; Williams, D.L.; Kao, R.L.; Kalbfleisch, J.H.; Browder, I.W.; Li, C. Preconditioning with a TLR2 specific ligand increases resistance to cerebral ischemia/reperfusion injury. J. Neuroimmunol. 2008, 199, 75-82. [CrossRef] [PubMed]

58. Lu, C.; Liu, L.; Chen, Y.; Ha, T.; Kelley, J.; Schweitzer, J.; Kalbfleisch, J.H.; Kao, R.L.; Williams, D.L.; Li, C. TLR2 ligand induces protection against cerebral ischemia/reperfusion injury via activation of phosphoinositide 3-Kinase/Akt signaling. J. Immunol. 2011, 187, 1458-1466. [CrossRef] [PubMed] 
59. Wang, H.; Naghavi, M.; Allen, C.; Barber, R.M.; Bhutta, Z.A.; Carter, A.; Casey, D.C.; Charlson, F.J.; Chen, A.Z.; Coates, M.M.; et al. Global, regional, and national life expectancy, all-cause mortality, and cause-specific mortality for 249 causes of death, 1980-2015: A systematic analysis for the global burden of disease study 2015. Lancet 2016, 388, 1459-1544. [CrossRef]

60. Pradillo, J.M.; Fernández-López, D.; García-Yébenes, I.; Sobrado, M.; Hurtado, O.; Moro, M.A.; Lizasoain, I. Toll-like receptor 4 is involved in neuroprotection afforded by ischemic preconditioning. J. Neurochem. 2009, 109, 287-294. [CrossRef] [PubMed]

61. Moraga, A.; Pradillo, J.M.; Cuartero, M.I.; Hernandez-Jimenez, M.; Oses, M.; Moro, M.A.; Lizasoain, I. Toll-like receptor 4 modulates cell migration and cortical neurogenesis after focal cerebral ischemia. FASEB J. 2014, 28, 4710-4718. [CrossRef] [PubMed]

62. D'Atri, L.P.; Schattner, M. Platelet toll-like receptors in thromboinflammation. Front. Biosci. Landmark Ed. 2017, 22, 1867-1883. [PubMed]

63. Blair, P.; Rex, S.; Vitseva, O.; Beaulieu, L.; Tanriverdi, K.; Chakrabarti, S.; Hayashi, C.; Genco, C.A.; Iafrati, M.; Freedman, J.E. Stimulation of toll-like receptor 2 in human platelets induces a thromboinflammatory response through activation of phosphoinositide 3-kinase. Circ. Res. 2009, 104, 346-354. [CrossRef] [PubMed]

64. Birks, E.J.; Felkin, L.E.; Banner, N.R.; Khaghani, A.; Barton, P.J.R.; Yacoub, M.H. Increased toll-like receptor 4 in the myocardium of patients requiring left ventricular assist devices. J. Heart Lung Transplant. Off. Publ. Int. Soc. Heart Transplant. 2004, 23, 228-235. [CrossRef]

65. Frantz, S.; Kobzik, L.; Kim, Y.D.; Fukazawa, R.; Medzhitov, R.; Lee, R.T.; Kelly, R.A. Toll4 (TLR4) expression in cardiac myocytes in normal and failing myocardium. J. Clin. Investig. 1999, 104, 271-280. [CrossRef] [PubMed]

66. Boyd, J.H.; Mathur, S.; Wang, Y.; Bateman, R.M.; Walley, K.R. Toll-like receptor stimulation in cardiomyoctes decreases contractility and initiates an NF-kB dependent inflammatory response. Cardiovasc. Res. 2006, 72, 384-393. [CrossRef] [PubMed]

67. Knuefermann, P.; Schwederski, M.; Velten, M.; Krings, P.; Ehrentraut, H.; Rudiger, M.; Boehm, O.; Fink, K.; Dreiner, U.; Grohe, C.; et al. Bacterial DNA induces myocardial inflammation and reduces cardiomyocyte contractility: Role of toll-like receptor 9. Cardiovasc. Res. 2008, 78, 26-35. [CrossRef] [PubMed]

68. Timmers, L.; Sluijter, J.P.G.; van Keulen, J.K.; Hoefer, I.E.; Nederhoff, M.G.J.; Goumans, M.-J.; Doevendans, P.A.; van Echteld, C.J.A.; Joles, J.A.; Quax, P.H.; et al. Toll-like receptor 4 mediates maladaptive left ventricular remodeling and impairs cardiac function after myocardial infarction. Circ. Res. 2008, 102, 257-264. [CrossRef] [PubMed]

69. Babu, A.N.; Meng, X.; Zou, N.; Yang, X.; Wang, M.; Song, Y.; Cleveland, J.C.; Weyant, M.; Banerjee, A.; Fullerton, D.A. Lipopolysaccharide stimulation of human aortic valve interstitial cells activates inflammation and osteogenesis. Ann. Thorac. Surg. 2008, 86, 71-76. [CrossRef] [PubMed]

70. Meng, X.; Ao, L.; Song, Y.; Babu, A.; Yang, X.; Wang, M.; Weyant, M.J.; Dinarello, C.A.; Cleveland, J.C.; Fullerton, D.A. Expression of functional toll-like receptors 2 and 4 in human aortic valve interstitial cells: Potential roles in aortic valve inflammation and stenosis. Am. J. Physiol. Cell Physiol. 2008, 294, C29-C35. [CrossRef] [PubMed]

71. Toli, K.; Paraskevas, K.I.; Poulakou, M.V.; Agrogiannis, G.; Kavantzas, N.; Xanthopoulos, V.; Iliopoulos, D.G.; Mantas, I.; Papachristodoulou, A.; Patsouris, E.; et al. Association between plasma levels and immunolocalization of cytokines in heart valve lesions: A possible target for treatment? Expert Opin. Ther. Targets 2008, 12, 1209-1215. [CrossRef] [PubMed]

72. Monnerat-Cahli, G.; Alonso, H.; Gallego, M.; Alarcón, M.L.; Bassani, R.A.; Casis, O.; Medei, E. Toll-like receptor 4 activation promotes cardiac arrhythmias by decreasing the transient outward potassium current (Ito) through an IRF3-dependent and MyD88-independent pathway. J. Mol. Cell. Cardiol. 2014, 76, 116-125. [CrossRef] [PubMed]

73. Mersmann, J.; Koch, A.; Tran, N.; Zimmermann, R.; Granja, T.F.; Larmann, J.; Herzog, C.; Theilmeier, G.; Bornstein, S.R.; Kirschning, C.J.; et al. Toll-like receptor 2 signaling triggers fatal arrhythmias upon myocardial ischemia-reperfusion. Crit. Care Med. 2010, 38, 1927-1932. [CrossRef] [PubMed]

74. McCarthy, C.G.; Goulopoulou, S.; Wenceslau, C.F.; Spitler, K.; Matsumoto, T.; Webb, R.C. Toll-like receptors and damage-associated molecular patterns: Novel links between inflammation and hypertension. AJP Heart Circ. Physiol. 2014, 306, H184-H196. [CrossRef] [PubMed] 
75. Singh, M.V.; Abboud, F.M. Toll-like receptors and hypertension. Am. J. Physiol. Regul. Integr. Comp. Physiol. 2014, 307, R501-R504. [CrossRef] [PubMed]

76. Bomfim, G.F.; Echem, C.; Martins, C.B.; Costa, T.J.; Sartoretto, S.M.; Dos Santos, R.A.; Oliveira, M.A.; Akamine, E.H.; Fortes, Z.B.; Tostes, R.C.; et al. Toll-like receptor 4 inhibition reduces vascular inflammation in spontaneously hypertensive rats. Life Sci. 2015, 122, 1-7. [CrossRef] [PubMed]

77. Hernanz, R.; Martínez-Revelles, S.; Palacios, R.; Martín, A.; Cachofeiro, V.; Aguado, A.; García-Redondo, L.; Barrús, M.T.; de Batista, P.R.; Briones, A.M.; et al. Toll-like receptor 4 contributes to vascular remodelling and endothelial dysfunction in angiotensin II-induced hypertension: TLR4 and vascular damage in hypertension. Br. J. Pharmacol. 2015, 172, 3159-3176. [CrossRef] [PubMed]

78. Erridge, C. Endogenous ligands of TLR2 and TLR4: Agonists or assistants? J. Leukoc. Biol. 2010, 87, 989-999. [CrossRef] [PubMed]

79. Harwani, S.C.; Chapleau, M.W.; Legge, K.L.; Ballas, Z.K.; Abboud, F.M. Neurohormonal modulation of the innate immune system is proinflammatory in the prehypertensive spontaneously hypertensive rat, a genetic model of essential hypertension. Circ. Res. 2012, 111, 1190-1197. [CrossRef] [PubMed]

80. Dange, R.B.; Agarwal, D.; Masson, G.S.; Vila, J.; Wilson, B.; Nair, A.; Francis, J. Central blockade of TLR4 improves cardiac function and attenuates myocardial inflammation in angiotensin II-induced hypertension. Cardiovasc. Res. 2014, 103, 17-27. [CrossRef] [PubMed]

81. Dange, R.B.; Agarwal, D.; Teruyama, R.; Francis, J. Toll-like receptor 4 inhibition within the paraventricular nucleus attenuates blood pressure and inflammatory response in a genetic model of hypertension. J. Neuroinflamm. 2015, 12, 31. [CrossRef] [PubMed]

82. Vijay-Kumar, M.; Aitken, J.D.; Carvalho, F.A.; Cullender, T.C.; Mwangi, S.; Srinivasan, S.; Sitaraman, S.V.; Knight, R.; Ley, R.E.; Gewirtz, A.T. Metabolic syndrome and altered gut microbiota in mice lacking toll-like receptor 5. Science 2010, 328, 228-231. [CrossRef] [PubMed]

83. McCarthy, C.G.; Wenceslau, C.F.; Goulopoulou, S.; Ogbi, S.; Baban, B.; Sullivan, J.C.; Matsumoto, T.; Webb, R.C. Circulating mitochondrial DNA and toll-like receptor 9 are associated with vascular dysfunction in spontaneously hypertensive rats. Cardiovasc. Res. 2015, 107, 119-130. [CrossRef] [PubMed]

84. Rodrigues, F.L.; Silva, L.E.V.; Hott, S.C.; Bomfim, G.F.; da Silva, C.A.A.; Fazan, R.; Resstel, L.B.M.; Tostes, R.C.; Carneiro, F.S. Toll-like receptor 9 plays a key role in the autonomic cardiac and baroreflex control of arterial pressure. Am. J. Physiol. Regul. Integr. Comp. Physiol. 2015, 308, R714-R723. [CrossRef] [PubMed]

85. Nemoto, S.; Vallejo, J.G.; Knuefermann, P.; Misra, A.; Defreitas, G.; Carabello, B.A.; Mann, D.L. Escherichia coli LPS-induced LV dysfunction: Role of toll-like receptor-4 in the adult heart. Am. J. Physiol. Heart Circ. Physiol. 2002, 282, H2316-H2323. [CrossRef] [PubMed]

86. Thomas, J.A.; Haudek, S.B.; Koroglu, T.; Tsen, M.F.; Bryant, D.D.; White, D.J.; Kusewitt, D.F.; Horton, J.W.; Giroir, B.P. IRAK1 deletion disrupts cardiac Toll/IL-1 signaling and protects against contractile dysfunction. Am. J. Physiol. Heart Circ. Physiol. 2003, 285, H597-H606. [CrossRef] [PubMed]

87. Baumgarten, G.; Knuefermann, P.; Schuhmacher, G.; Vervölgyi, V.; von Rappard, J.; Dreiner, U.; Fink, K.; Djoufack, C.; Hoeft, A.; Grohé, C.; et al. Toll-like receptor 4, nitric oxide, and myocardial depression in endotoxemia. Shock Augusta Ga 2006, 25, 43-49. [CrossRef]

88. Knuefermann, P.; Sakata, Y.; Baker, J.S.; Huang, C.-H.; Sekiguchi, K.; Hardarson, H.S.; Takeuchi, O.; Akira, S.; Vallejo, J.G. Toll-like receptor 2 mediates Staphylococcus aureus-induced myocardial dysfunction and cytokine production in the heart. Circulation 2004, 110, 3693-3698. [CrossRef] [PubMed]

89. Hardarson, H.S.; Baker, J.S.; Yang, Z.; Purevjav, E.; Huang, C.-H.; Alexopoulou, L.; Li, N.; Flavell, R.A.; Bowles, N.E.; Vallejo, J.G. Toll-like receptor 3 is an essential component of the innate stress response in virus-induced cardiac injury. Am. J. Physiol. Heart Circ. Physiol. 2007, 292, H251-H258. [CrossRef] [PubMed]

90. Negishi, H.; Osawa, T.; Ogami, K.; Ouyang, X.; Sakaguchi, S.; Koshiba, R.; Yanai, H.; Seko, Y.; Shitara, H.; Bishop, K.; et al. A critical link between toll-like receptor 3 and type II interferon signaling pathways in antiviral innate immunity. Proc. Natl. Acad. Sci. USA 2008, 105, 20446-20451. [CrossRef] [PubMed]

91. Pagni, P.P.; Traub, S.; Demaria, O.; Chasson, L.; Alexopoulou, L. Contribution of TLR7 and TLR9 signaling to the susceptibility of MyD88-deficient mice to myocarditis. Autoimmunity 2010, 43, 275-287. [CrossRef] [PubMed]

92. Fuse, K.; Chan, G.; Liu, Y.; Gudgeon, P.; Husain, M.; Chen, M.; Yeh, W.-C.; Akira, S.; Liu, P.P. Myeloid differentiation factor-88 plays a crucial role in the pathogenesis of Coxsackievirus B3-induced myocarditis and influences type I interferon production. Circulation 2005, 112, 2276-2285. [CrossRef] [PubMed] 
93. Norman, A.W. From vitamin D to hormone D: Fundamentals of the vitamin D endocrine system essential for good health. Am. J. Clin. Nutr. 2008, 88, 491S-499S. [PubMed]

94. Dusso, A.S.; Brown, A.J.; Slatopolsky, E. Vitamin D. Am. J. Physiol. Renal Physiol. 2005, 289, F8-F28. [CrossRef] [PubMed]

95. Lowe, K.E.; Maiyar, A.C.; Norman, A.W. Vitamin D-mediated gene expression. Crit. Rev. Eukaryot. Gene Expr. 1992, 2, 65-109. [PubMed]

96. Bouillon, R.; Carmeliet, G.; Verlinden, L.; van Etten, E.; Verstuyf, A.; Luderer, H.F.; Lieben, L.; Mathieu, C.; Demay, M. Vitamin D and human health: Lessons from vitamin D receptor null mice. Endocr. Rev. 2008, 29, 726-776. [CrossRef] [PubMed]

97. Holick, M.F. Vitamin D deficiency. N. Engl. J. Med. 2007, 357, 266-281. [CrossRef] [PubMed]

98. Veugelers, P.J.; Pham, T.-M.; Ekwaru, J.P. Optimal vitamin D supplementation doses that minimize the risk for both low and high serum 25-hydroxyvitamin D concentrations in the general population. Nutrients 2015, 7, 10189-10208. [CrossRef] [PubMed]

99. Dawson-Hughes, B.; Heaney, R.P.; Holick, M.F.; Lips, P.; Meunier, P.J.; Vieth, R. Estimates of optimal vitamin D status. Osteoporos. Int. J. Establ. Result Coop. Eur. Found. Osteoporos. Natl. Osteoporos. Found. USA 2005, 16, 713-716. [CrossRef] [PubMed]

100. Spiro, A.; Buttriss, J.L. Vitamin D: An overview of vitamin D status and intake in Europe. Nutr. Bull. 2014, 39, 322-350. [CrossRef] [PubMed]

101. Palacios, C.; Gonzalez, L. Is vitamin D deficiency a major global public health problem? J. Steroid Biochem. Mol. Biol. 2014, 144, 138-145. [CrossRef] [PubMed]

102. Wahl, D.A.; Cooper, C.; Ebeling, P.R.; Eggersdorfer, M.; Hilger, J.; Hoffmann, K.; Josse, R.; Kanis, J.A.; Mithal, A.; Pierroz, D.D.; et al. A global representation of vitamin D status in healthy populations. Arch. Osteoporos. 2012, 7, 155-172. [CrossRef] [PubMed]

103. Forrest, K.Y.Z.; Stuhldreher, W.L. Prevalence and correlates of vitamin D deficiency in US adults. Nutr. Res. 2011, 31, 48-54. [CrossRef] [PubMed]

104. Holick, M.F. Vitamin D: Extraskeletal Health. Rheum. Dis. Clin. N. Am. 2012, 38, 141-160. [CrossRef] [PubMed]

105. Wacker, M.; Holick, M. Vitamin D-Effects on skeletal and extraskeletal health and the need for supplementation. Nutrients 2013, 5, 111-148. [CrossRef] [PubMed]

106. Cashman, K.D. A review of vitamin D status and CVD. Proc. Nutr. Soc. 2014, 73, 65-72. [CrossRef] [PubMed]

107. Giovannucci, E. 25-Hydroxyvitamin D and Risk of Myocardial Infarction in MenA Prospective Study. Arch. Intern. Med. 2008, 168, 1174. [CrossRef] [PubMed]

108. Kendrick, J.; Targher, G.; Smits, G.; Chonchol, M. 25-Hydroxyvitamin D deficiency is independently associated with cardiovascular disease in the third national health and nutrition examination survey. Atherosclerosis 2009, 205, 255-260. [CrossRef] [PubMed]

109. Targher, G.; Pichiri, I.; Lippi, G. Vitamin D, thrombosis, and hemostasis: More than skin deep. Semin. Thromb. Hemost. 2012, 38, 114-124. [CrossRef] [PubMed]

110. Mousa, A.; Naderpoor, N.; de Courten, M.P.J.; Scragg, R.; de Courten, B. 25-hydroxyvitamin D is associated with adiposity and cardiometabolic risk factors in a predominantly vitamin D-deficient and overweight/obese but otherwise healthy cohort. J. Steroid Biochem. Mol. Biol. 2017, 173, 258-264. [CrossRef] [PubMed]

111. Meehan, M.; Penckofer, S. The role of vitamin D in the aging adult. J. Aging Gerontol. 2014, 2, 60-71. [CrossRef] [PubMed]

112. Gouni-Berthold, I.; Krone, W.; Berthold, H.K. Vitamin D and cardiovascular disease. Curr. Vasc. Pharmacol. 2009, 7, 414-422. [CrossRef] [PubMed]

113. Rejnmark, L.; Bislev, L.S.; Cashman, K.D.; Eiríksdottir, G.; Gaksch, M.; Grübler, M.; Grimnes, G.; Gudnason, V.; Lips, P.; Pilz, S.; et al. Non-skeletal health effects of vitamin D supplementation: A systematic review on findings from meta-analyses summarizing trial data. PLoS ONE 2017, 12, e0180512. [CrossRef] [PubMed]

114. Sokol, S.I.; Tsang, P.; Aggarwal, V.; Melamed, M.L.; Srinivas, V.S. Vitamin D status and risk of cardiovascular events: Lessons learned via systematic review and meta-analysis. Cardiol. Rev. 2011, 19, 192-201. [CrossRef] [PubMed]

115. Brewer, L.C.; Michos, E.D.; Reis, J.P. Vitamin D in atherosclerosis, vascular disease, and endothelial function. Curr. Drug Targets 2011, 12, 54-60. [CrossRef] [PubMed] 
116. García-Canton, C.; Bosch, E.; Ramírez, A.; Gonzalez, Y.; Auyanet, I.; Guerra, R.; Perez, M.A.; Fernández, E.; Toledo, A.; Lago, M.; et al. Vascular calcification and 25-hydroxyvitamin D levels in non-dialysis patients with chronic kidney disease stages 4 and 5. Nephrol. Dial. Transplant. Off. Publ. Eur. Dial. Transpl. Assoc. Eur. Ren. Assoc. 2011, 26, 2250-2256. [CrossRef] [PubMed]

117. Kassi, E.; Adamopoulos, C.; Basdra, E.K.; Papavassiliou, A.G. Role of Vitamin D in Atherosclerosis. Circulation 2013, 128, 2517-2531. [CrossRef] [PubMed]

118. Merke, J.; Milde, P.; Lewicka, S.; Hügel, U.; Klaus, G.; Mangelsdorf, D.J.; Haussler, M.R.; Rauterberg, E.W.; Ritz, E. Identification and regulation of 1,25-dihydroxyvitamin $\mathrm{D}_{3}$ receptor activity and biosynthesis of 1,25-dihydroxyvitamin $\mathrm{D}_{3}$. Studies in cultured bovine aortic endothelial cells and human dermal capillaries. J. Clin. Investig. 1989, 83, 1903-1915. [CrossRef] [PubMed]

119. Zehnder, D.; Bland, R.; Chana, R.S.; Wheeler, D.C.; Howie, A.J.; Williams, M.C.; Stewart, P.M.; Hewison, M. Synthesis of 1,25-dihydroxyvitamin $\mathrm{D}_{3}$ by human endothelial cells is regulated by inflammatory cytokines: A novel autocrine determinant of vascular cell adhesion. J. Am. Soc. Nephrol. JASN 2002, 13, 621-629. [PubMed]

120. Molinari, C.; Uberti, F.; Grossini, E.; Vacca, G.; Carda, S.; Invernizzi, M.; Cisari, C. 1 1 25dihydroxycholecalciferol induces nitric oxide production in cultured endothelial cells. Cell. Physiol. Biochem. Int. J. Exp. Cell. Physiol. Biochem. Pharmacol. 2011, 27, 661-668. [CrossRef] [PubMed]

121. Queen, L.R.; Ji, Y.; Xu, B.; Young, L.; Yao, K.; Wyatt, A.W.; Rowlands, D.J.; Siow, R.C.M.; Mann, G.E.; Ferro, A. Mechanisms underlying $\beta_{2}$-adrenoceptor-mediated nitric oxide generation by human umbilical vein endothelial cells: Endothelial $\beta$-adrenoceptors and nitric oxide. J. Physiol. 2006, 576, 585-594. [CrossRef] [PubMed]

122. Hirata, M.; Serizawa, K.; Aizawa, K.; Yogo, K.; Tashiro, Y.; Takeda, S.; Moriguchi, Y.; Endo, K.; Fukagawa, M. 22-Oxacalcitriol prevents progression of endothelial dysfunction through antioxidative effects in rats with type 2 diabetes and early-stage nephropathy. Nephrol. Dial. Transplant. 2013, 28, 1166-1174. [CrossRef] [PubMed]

123. Andrukhova, O.; Slavic, S.; Zeitz, U.; Riesen, S.C.; Heppelmann, M.S.; Ambrisko, T.D.; Markovic, M.; Kuebler, W.M.; Erben, R.G. Vitamin D is a regulator of endothelial nitric oxide synthase and arterial stiffness in mice. Mol. Endocrinol. 2014, 28, 53-64. [CrossRef] [PubMed]

124. Equils, O.; Naiki, Y.; Shapiro, A.M.; Michelsen, K.; Lu, D.; Adams, J.; Jordan, S. 1,25-Dihydroxyvitamin D inhibits lipopolysaccharide-induced immune activation in human endothelial cells. Clin. Exp. Immunol. 2006, 143, 58-64. [CrossRef] [PubMed]

125. Martinesi, M.; Bruni, S.; Stio, M.; Treves, C. 1,25-Dihydroxyvitamin $D_{3}$ inhibits tumor necrosis factor-alpha-induced adhesion molecule expression in endothelial cells. Cell Biol. Int. 2006, 30, 365-375. [CrossRef] [PubMed]

126. Collins, T.; Read, M.A.; Neish, A.S.; Whitley, M.Z.; Thanos, D.; Maniatis, T. Transcriptional regulation of endothelial cell adhesion molecules: NF-K B and cytokine-inducible enhancers. FASEB J. Off. Publ. Fed. Am. Soc. Exp. Biol. 1995, 9, 899-909.

127. Talmor, Y.; Bernheim, J.; Klein, O.; Green, J.; Rashid, G. Calcitriol blunts pro-atherosclerotic parameters through NF-kB and p38 in vitro. Eur. J. Clin. Investig. 2008, 38, 548-554. [CrossRef] [PubMed]

128. Stach, K.; Kälsch, A.-I.; Nguyen, X.D.; Elmas, E.; Kralev, S.; Lang, S.; Weiss, C.; Borggrefe, M.; Kälsch, T. $1 \alpha, 25$-Dihydroxyvitamin $\mathrm{D}_{3}$ Attenuates Platelet Activation and the Expression of VCAM-1 and MT1-MMP in Human Endothelial Cells. Cardiology 2011, 118, 107-115. [CrossRef] [PubMed]

129. Krishnan, A.V.; Feldman, D. Molecular pathways mediating the anti-inflammatory effects of calcitriol: Implications for prostate cancer chemoprevention and treatment. Endocr. Relat. Cancer 2010, 17, R19-R38. [CrossRef] [PubMed]

130. Chenevard, R. Selective COX-2 inhibition improves endothelial function in coronary artery disease. Circulation 2003, 107, 405-409. [CrossRef] [PubMed]

131. Vanhoutte, P.M.; Feletou, M.; Taddei, S. Endothelium-dependent contractions in hypertension. Br. J. Pharmacol. 2005, 144, 449-458. [CrossRef] [PubMed]

132. Wong, M.S.K.; Man, R.Y.K.; Vanhoutte, P.M. Calcium-independent phospholipase $\mathrm{A}_{2}$ plays a key role in the endothelium-dependent contractions to acetylcholine in the aorta of the spontaneously hypertensive rat. AJP Heart Circ. Physiol. 2010, 298, H1260-H1266. [CrossRef] [PubMed] 
133. Wong, M.S.K.; Delansorne, R.; Man, R.Y.K.; Vanhoutte, P.M. Vitamin D derivatives acutely reduce endothelium-dependent contractions in the aorta of the spontaneously hypertensive rat. AJP Heart Circ. Physiol. 2008, 295, H289-H296. [CrossRef] [PubMed]

134. Takeda, M.; Yamashita, T.; Sasaki, N.; Nakajima, K.; Kita, T.; Shinohara, M.; Ishida, T.; Hirata, K. Oral administration of an active form of vitamin $\mathrm{D}_{3}$ (calcitriol) decreases atherosclerosis in mice by inducing regulatory $\mathrm{T}$ cells and immature dendritic cells with tolerogenic functions. Arterioscler. Thromb. Vasc. Biol. 2010, 30, 2495-2503. [CrossRef] [PubMed]

135. Bobryshev, Y.V. Vitamin $\mathrm{D}_{3}$ suppresses immune reactions in atherosclerosis, affecting regulatory $\mathrm{T}$ cells and dendritic cell function. Arterioscler. Thromb. Vasc. Biol. 2010, 30, 2317-2319. [CrossRef] [PubMed]

136. Mangge, H.; Weghuber, D.; Prassl, R.; Haara, A.; Schnedl, W.; Postolache, T.T.; Fuchs, D. The role of vitamin D in atherosclerosis inflammation revisited: More a bystander than a player? Curr. Vasc. Pharmacol. 2015, 13, 392-398. [CrossRef] [PubMed]

137. Nunes, J.P.L. Troponin I, but not BNP, is associated with phosphorus, calcium and vitamin D in stable coronary artery disease. Kidney Blood Press. Res. 2013, 37, 43-47. [CrossRef] [PubMed]

138. De Metrio, M.; Milazzo, V.; Rubino, M.; Cabiati, A.; Moltrasio, M.; Marana, I.; Campodonico, J.; Cosentino, N.; Veglia, F.; Bonomi, A.; et al. Vitamin D plasma levels and in-hospital and 1-year outcomes in acute coronary syndromes: A prospective study. Medicine (Baltimore) 2015, 94, e857. [CrossRef] [PubMed]

139. Naesgaard, P.A.; Pönitz, V.; Aarsetoey, H.; Brügger-Andersen, T.; Grundt, H.; Harris, W.S.; Staines, H.; Nilsen, D.W.T. Prognostic utility of vitamin D in acute coronary syndrome patients in coastal norway. Dis. Markers 2015, 2015, 1-11. [CrossRef] [PubMed]

140. Kumar, S.; Saxena, P. To evaluate the role of plasma vitamin D level as a prognostic marker and its relation to in-hospital complications in patients with acute coronary syndrome. Int. J. Adv. Med. 2016, 976-981. [CrossRef]

141. Gondim, F.; Caribé, A.; Vasconcelos, K.; Segundo, A.; Bandeira, F. Vitamin D deficiency is associated with severity of acute coronary syndrome in patients with type 2 diabetes and high rates of sun exposure. Clin. Med. Insights Endocrinol. Diabetes 2016, 37-41. [CrossRef] [PubMed]

142. Pilz, S.; Tomaschitz, A.; Drechsler, C.; Zittermann, A.; Dekker, J.M.; März, W. Vitamin D supplementation: A promising approach for the prevention and treatment of strokes. Curr. Drug Targets 2011, 12, 88-96. [CrossRef] [PubMed]

143. Narasimhan, S. Role of vitamin D in the outcome of ischemic stroke- A randomized controlled trial. J. Clin. Diagn. Res. 2017. [CrossRef] [PubMed]

144. Rezaei, Y.; Khademvatani, K.; Seyyed-Mohammadzad, M.H.; Akbari, M.; Eskandari, R.; Rostamzadeh, A. The relationship between vitamin D status and idiopathic lower-extremity deep vein thrombosis. Int. J. Gen. Med. 2014, 7, 303-309. [CrossRef] [PubMed]

145. Entezari-Maleki, T.; Hajhossein Talasaz, A.; Salarifar, M.; Hadjibabaie, M.; Javadi, M.R.; Bozorgi, A.; Jenab, Y.; Boroumand, M.A.; Gholami, K. Plasma vitamin D status and its correlation with risk factors of thrombosis, P-selectin and HS-CRP level in patients with venous thromboembolism; the first study of iranian population. Iran. J. Pharm. Res. IJPR 2014, 13, 319-327. [PubMed]

146. Brilla, C.G. The cardiac structure-function relationship and the renin-angiotensin-aldosterone system in hypertension and heart failure. Curr. Opin. Cardiol. 1994, 9 (Suppl. 1), S2-S10; discussion S10-S11. [CrossRef] [PubMed]

147. Sigurdsson, A.; Swedberg, K. Neurohormonal activation and congestive heart failure: Today's experience with ACE inhibitors and rationale for their use. Eur. Heart J. 1995, 16 (Suppl. N), 65-72. [CrossRef] [PubMed]

148. Sackner-Bernstein, J.D.; Mancini, D.M. Rationale for treatment of patients with chronic heart failure with adrenergic blockade. JAMA 1995, 274, 1462-1467. [CrossRef] [PubMed]

149. Zittermann, A.; Schleithoff, S.S.; Koerfer, R. Vitamin D insufficiency in congestive heart failure: Why and what to do about it? Heart Fail. Rev. 2006, 11, 25-33. [CrossRef] [PubMed]

150. Patel, R.; Rizvi, A.A. Vitamin D deficiency in patients with congestive heart failure: Mechanisms, manifestations, and management. South. Med. J. 2011, 104, 325-330. [CrossRef] [PubMed]

151. Andersson, P.; Rydberg, E.; Willenheimer, R. Primary hyperparathyroidism and heart disease-A review. Eur. Heart J. 2004, 25, 1776-1787. [CrossRef] [PubMed] 
152. Meredith, A.; Boroomand, S.; Carthy, J.; Luo, Z.; McManus, B. 1,25 Dihydroxyvitamin $\mathrm{D}_{3}$ inhibits TGF 31 -mediated primary human cardiac myofibroblast activation. PLoS ONE 2015, 10, e0128655. [CrossRef] [PubMed]

153. Bae, S.; Singh, S.S.; Yu, H.; Lee, J.Y.; Cho, B.R.; Kang, P.M. Vitamin D signaling pathway plays an important role in the development of heart failure after myocardial infarction. J. Appl. Physiol. 2013, 114, 979-987. [CrossRef] [PubMed]

154. Mihos, C.G.; De La Cruz, J.A.; Hernandez, A.; Santana, O. Vitamin D Deficiency and supplementation in cardiovascular disorders. Cardiol. Rev. 2017, 25, 189-196. [CrossRef] [PubMed]

155. Schleithoff, S.S.; Zittermann, A.; Tenderich, G.; Berthold, H.K.; Stehle, P.; Koerfer, R. Vitamin D supplementation improves cytokine profiles in patients with congestive heart failure: A double-blind, randomized, placebo-controlled trial. Am. J. Clin. Nutr. 2006, 83, 754-759. [PubMed]

156. Camici, M.; Galetta, F.; Franzoni, F.; Carpi, A.; Zangeneh, F. Vitamin D and heart. Intern. Emerg. Med. 2013, 8 (Suppl. 1), S5-S9. [CrossRef] [PubMed]

157. Ameri, P.; Canepa, M.; Milaneschi, Y.; Spallarossa, P.; Leoncini, G.; Giallauria, F.; Strait, J.B.; Lakatta, E.G.; Brunelli, C.; Murialdo, G.; et al. Relationship between vitamin D status and left ventricular geometry in a healthy population: Results from the baltimore longitudinal study of aging. J. Intern. Med. 2013, 273, 253-262. [CrossRef] [PubMed]

158. Czarny, M.J.; Resar, J.R. Diagnosis and management of valvular aortic stenosis. Clin. Med. Insights Cardiol. 2014, 8 (Suppl. 1). [CrossRef] [PubMed]

159. Manning, W.J. Asymptomatic aortic stenosis in the elderly: A clinical review. JAMA 2013, 310, 1490-1497. [CrossRef] [PubMed]

160. Otto, C.M.; Lind, B.K.; Kitzman, D.W.; Gersh, B.J.; Siscovick, D.S. Association of aortic-valve sclerosis with cardiovascular mortality and morbidity in the elderly. N. Engl. J. Med. 1999, 341, 142-147. [CrossRef] [PubMed]

161. Hekimian, G.; Boutten, A.; Flamant, M.; Duval, X.; Dehoux, M.; Benessiano, J.; Huart, V.; Dupré, T.; Berjeb, N.; Tubach, F.; et al. Progression of aortic valve stenosis is associated with bone remodelling and secondary hyperparathyroidism in elderly patients-The COFRASA study. Eur. Heart J. 2013, 34, 1915-1922. [CrossRef] [PubMed]

162. Linhartová, K.; Veselka, J.; Sterbáková, G.; Racek, J.; Topolcan, O.; Cerbák, R. Parathyroid hormone and vitamin D levels are independently associated with calcific aortic stenosis. Circ. J. Off. J. Jpn. Circ. Soc. 2008, 72, 245-250. [CrossRef]

163. Eren, E.; Ellidag, H.Y.; Cekin, Y.; Ayoglu, R.U.; Sekercioglu, A.O.; Yılmaz, N. Heart valve disease: The role of calcidiol deficiency, elevated parathyroid hormone levels and oxidative stress in mitral and aortic valve insufficiency. Redox Rep. Commun. Free Radic. Res. 2014, 19, 34-39. [CrossRef] [PubMed]

164. Vitezova, A.; Cartolano, N.S.; Heeringa, J.; Zillikens, M.C.; Hofman, A.; Franco, O.H.; Kiefte-de Jong, J.C. Vitamin D and the risk of atrial fibrillation-The rotterdam study. PLoS ONE 2015, 10, e0125161. [CrossRef] [PubMed]

165. Alonso, A.; Misialek, J.R.; Michos, E.D.; Eckfeldt, J.; Selvin, E.; Soliman, E.Z.; Chen, L.Y.; Gross, M.D.; Lutsey, P.L. Serum 25-hydroxyvitamin D and the incidence of atrial fibrillation: The atherosclerosis risk in communities (ARIC) STUDY. Europace 2016, 18, 1143-1149. [CrossRef] [PubMed]

166. Zhang, Z.; Yang, Y.; Ng, C.Y.; Wang, D.; Wang, J.; Li, G.; Liu, T. Meta-analysis of vitamin D deficiency and risk of atrial fibrillation: Vitamin D deficiency and risk of AF. Clin. Cardiol. 2016, 39, 537-543. [CrossRef] [PubMed]

167. Gode, S.; Aksu, T.; Demirel, A.; Sunbul, M.; Gul, M.; Bakır, I.; Yeniterzi, M. Effect of vitamin D deficiency on the development of postoperative atrial fibrillation in coronary artery bypass patients. J. Cardiovasc. Thorac. Res. 2016, 8, 140-146. [CrossRef] [PubMed]

168. Cerit, L.; Kemal, H.; Gulsen, K.; Ozcem, B.; Cerit, Z.; Duygu, H. Relationship between vitamin D and the development of atrial fibrillation after on-pump coronary artery bypass graft surgery. Cardiovasc. J. Afr. 2017, 28, 104-107. [CrossRef] [PubMed]

169. Belen, E.; Aykan, A.C.; Kalaycioglu, E.; Sungur, M.A.; Sungur, A.; Cetin, M. Low-level vitamin D is associated with atrial fibrillation in patients with chronic heart failure. Adv. Clin. Exp. Med. 2016, 25, 51-57. [CrossRef] [PubMed] 
170. Kiuchi, M.G.; Ramalho e Silva, G.; Paz, L.M.R.; Chen, S.; Hoye, N.A.; Souto, G.L.L. Influence of vitamin D levels on the treatment of premature ventricular complexes in patients with chronic kidney disease. IJC Metab. Endocr. 2017, 14, 53-58. [CrossRef]

171. Pilz, S.; Tomaschitz, A. Role of vitamin D in arterial hypertension. Expert Rev. Cardiovasc. Ther. 2010, 8, 1599-1608. [CrossRef] [PubMed]

172. Resnick, L.M.; Müller, F.B.; Laragh, J.H. Calcium-regulating hormones in essential hypertension. Relation to plasma renin activity and sodium metabolism. Ann. Intern. Med. 1986, 105, 649-654. [CrossRef] [PubMed]

173. Carrara, D.; Bernini, M.; Bacca, A.; Rugani, I.; Duranti, E.; Virdis, A.; Ghiadoni, L.; Taddei, S.; Bernini, G. Cholecalciferol administration blunts the systemic renin-angiotensin system in essential hypertensives with hypovitaminosis D. J. Renin-Angiotensin-Aldosterone Syst. JRAAS 2014, 15, 82-87. [CrossRef] [PubMed]

174. Vaidya, A.; Forman, J.P.; Williams, J.S. Vitamin D and the vascular sensitivity to angiotensin II in obese Caucasians with hypertension. J. Hum. Hypertens. 2011, 25, 672-678. [CrossRef] [PubMed]

175. Xiang, W.; Kong, J.; Chen, S.; Cao, L.-P.; Qiao, G.; Zheng, W.; Liu, W.; Li, X.; Gardner, D.G.; Li, Y.C. Cardiac hypertrophy in vitamin D receptor knockout mice: Role of the systemic and cardiac renin-angiotensin systems. Am. J. Physiol. Endocrinol. Metab. 2005, 288, E125-E132. [CrossRef] [PubMed]

176. Lind, L.; Hänni, A.; Lithell, H.; Hvarfner, A.; Sörensen, O.H.; Ljunghall, S. Vitamin D is related to blood pressure and other cardiovascular risk factors in middle-aged men. Am. J. Hypertens. 1995, 8, 894-901. [CrossRef]

177. Kunutsor, S.K.; Apekey, T.A.; Steur, M. Vitamin D and risk of future hypertension: Meta-analysis of 283,537 participants. Eur. J. Epidemiol. 2013, 28, 205-221. [CrossRef] [PubMed]

178. Scragg, R.; Sowers, M.; Bell, C. Serum 25-hydroxyvitamin D, ethnicity, and blood pressure in the third national health and nutrition examination survey. Am. J. Hypertens. 2007, 20, 713-719. [CrossRef] [PubMed]

179. Forman, J.P.; Curhan, G.C.; Taylor, E.N. Plasma 25-hydroxyvitamin D levels and risk of incident hypertension among young women. Hypertension 2008, 52, 828-832. [CrossRef] [PubMed]

180. Margolis, K.L.; Ray, R.M.; van Horn, L.; Manson, J.E.; Allison, M.A.; Black, H.R.; Beresford, S.A.A.; Connelly, S.A.; Curb, J.D.; Grimm, R.H.; et al. Women's health initiative investigators effect of calcium and vitamin D supplementation on blood pressure: The women's health Initiative randomized Trial. Hypertension 2008, 52, 847-855. [CrossRef]

181. Van Ballegooijen, A.J.; Kestenbaum, B.; Sachs, M.C.; de Boer, I.H.; Siscovick, D.S.; Hoofnagle, A.N.; Ix, J.H.; Visser, M.; Brouwer, I.A. Association of 25-hydroxyvitamin D and parathyroid hormone with incident hypertension. J. Am. Coll. Cardiol. 2014, 63, 1214-1222. [CrossRef] [PubMed]

182. Braun, A.; Chang, D.; Mahadevappa, K.; Gibbons, F.K.; Liu, Y.; Giovannucci, E.; Christopher, K.B. Association of low serum 25-hydroxyvitamin D levels and mortality in the critically ill. Crit. Care Med. 2011, 39, 671-677. [CrossRef] [PubMed]

183. Christopher, K.B. Vitamin D supplementation in the ICU patient. Curr. Opin. Clin. Nutr. Metab. Care 2015, 18, 187-192. [CrossRef] [PubMed]

184. Watkins, H.; Ashrafian, H.; Redwood, C. Inherited cardiomyopathies. N. Engl. J. Med. 2011, 364, $1643-1656$. [CrossRef] [PubMed]

185. Fang, L.-H.; Fan, X.-C. Expression of Vitamin D receptor in the myocardium of mice with viral myocarditis. Zhongguo Dang Dai Er Ke Za Zhi/Chin. J. Contemp. Pediatr. 2015, 17, 1007-1012.

186. Biragyn, A.; Ruffini, P.A.; Leifer, C.A.; Klyushnenkova, E.; Shakhov, A.; Chertov, O.; Shirakawa, A.K.; Farber, J.M.; Segal, D.M.; Oppenheim, J.J.; et al. Toll-like receptor 4-dependent activation of dendritic cells by $\beta$-defensin 2. Science 2002, 298, 1025-1029. [CrossRef] [PubMed]

187. Griffin, M.D.; Lutz, W.H.; Phan, V.A.; Bachman, L.A.; McKean, D.J.; Kumar, R. Potent inhibition of dendritic cell differentiation and maturation by vitamin D analogs. Biochem. Biophys. Res. Commun. 2000, 270, 701-708. [CrossRef] [PubMed]

188. Kabelitz, D. Expression and function of toll-like receptors in T lymphocytes. Curr. Opin. Immunol. 2007, 19, 39-45. [CrossRef] [PubMed]

189. Provvedini, D.M.; Tsoukas, C.D.; Deftos, L.J.; Manolagas, S.C. 1,25-dihydroxyvitamin $\mathrm{D}_{3}$ receptors in human leukocytes. Science 1983, 221, 1181-1183. [CrossRef] [PubMed]

190. Rigby, W.F.; Stacy, T.; Fanger, M.W. Inhibition of T lymphocyte mitogenesis by 1,25-dihydroxyvitamin $\mathrm{D}_{3}$ (calcitriol). J. Clin. Investig. 1984, 74, 1451-1455. [CrossRef] [PubMed] 
191. Peng, G.; Guo, Z.; Kiniwa, Y.; Voo, K.S.; Peng, W.; Fu, T.; Wang, D.Y.; Li, Y.; Wang, H.Y.; Wang, R.-F. Toll-like receptor 8-mediated reversal of $\mathrm{CD}^{+}$regulatory $\mathrm{T}$ cell function. Science 2005, 309, 1380-1384. [CrossRef] [PubMed]

192. Adorini, L.; Penna, G.; Giarratana, N.; Uskokovic, M. Tolerogenic dendritic cells induced by vitamin D receptor ligands enhance regulatory $\mathrm{T}$ cells inhibiting allograft rejection and autoimmune diseases. J. Cell. Biochem. 2003, 88, 227-233. [CrossRef] [PubMed]

193. Rozkova, D.; Horvath, R.; Bartunkova, J.; Spisek, R. Glucocorticoids severely impair differentiation and antigen presenting function of dendritic cells despite upregulation of toll-like receptors. Clin. Immunol. Orlando FL 2006, 120, 260-271. [CrossRef] [PubMed]

194. Ding, C.; Wilding, J.P.H.; Bing, C. 1,25-dihydroxyvitamin $\mathrm{D}_{3}$ protects against macrophage-induced activation of NF- $\kappa \mathrm{B}$ and MAPK signalling and chemokine release in human adipocytes. PLoS ONE 2013, 8, e61707. [CrossRef]

195. Liu, P.T.; Stenger, S.; Li, H.; Wenzel, L.; Tan, B.H.; Krutzik, S.R.; Ochoa, M.T.; Schauber, J.; Wu, K.; Meinken, C.; et al. Toll-like receptor triggering of a vitamin D-mediated human antimicrobial response. Science 2006, 311, 1770-1773. [CrossRef] [PubMed]

196. Baeke, F.; Takiishi, T.; Korf, H.; Gysemans, C.; Mathieu, C. Vitamin D: Modulator of the immune system. Curr. Opin. Pharmacol. 2010, 10, 482-496. [CrossRef] [PubMed]

197. Netea, M.G.; van der Meer, J.W.M.; Sutmuller, R.P.; Adema, G.J.; Kullberg, B.-J. From the Th1/Th2 paradigm towards a toll-like receptor/T-Helper bias. Antimicrob. Agents Chemother. 2005, 49, 3991-3996. [CrossRef] [PubMed]

198. Abdul-Cader, M.S.; Amarasinghe, A.; Abdul-Careem, M.F. Activation of toll-like receptor signaling pathways leading to nitric oxide-mediated antiviral responses. Arch. Virol. 2016, 161, 2075-2086. [CrossRef] [PubMed]

199. Do, J.E.; Kwon, S.Y.; Park, S.; Lee, E.-S. Effects of vitamin D on expression of toll-like receptors of monocytes from patients with Behcet's disease. Rheumatol. Oxf. Engl. 2008, 47, 840-848. [CrossRef] [PubMed]

200. Devaraj, S.; Yun, J.-M.; Duncan-Staley, C.R.; Jialal, I. Low vitamin D levels correlate with the proinflammatory state in type 1 diabetic subjects with and without microvascular complications. Am. J. Clin. Pathol. 2011, 135, 429-433. [CrossRef] [PubMed]

201. Alvarez-Rodriguez, L.; Lopez-Hoyos, M.; Garcia-Unzueta, M.; Amado, J.A.; Cacho, P.M.; Martinez-Taboada, V.M. Age and low levels of circulating vitamin D are associated with impaired innate immune function. J. Leukoc. Biol. 2012, 91, 829-838. [CrossRef] [PubMed]

202. Ojaimi, S.; Skinner, N.A.; Strauss, B.J.; Sundararajan, V.; Woolley, I.; Visvanathan, K. Vitamin D deficiency impacts on expression of toll-like receptor-2 and cytokine profile: A pilot study. J. Transl. Med. 2013, 11, 176. [CrossRef] [PubMed]

203. Du, T.; Zhou, Z.-G.; You, S.; Huang, G.; Lin, J.; Yang, L.; Li, X.; Zhou, W.-D.; Chao, C. Modulation of monocyte hyperresponsiveness to TLR ligands by 1,25-dihydroxy-vitamin D3 from LADA and T2DM. Diabetes Res. Clin. Pract. 2009, 83, 208-214. [CrossRef] [PubMed]

204. Qian, L.; Wang, H.; Wu, F.; Li, M.; Chen, W.; Lv, L. Vitamin D3 alters toll-like receptor 4 signaling in monocytes of pregnant women at risk for preeclampsia. Int. J. Clin. Exp. Med. 2015, 8, 18041-18049. [PubMed]

205. Dickie, L.J.; Church, L.D.; Coulthard, L.R.; Mathews, R.J.; Emery, P.; McDermott, M.F. Vitamin D3 down-regulates intracellular toll-like receptor 9 expression and toll-like receptor 9-induced IL-6 production in human monocytes. Rheumatology 2010, 49, 1466-1471. [CrossRef] [PubMed]

206. Földes, G.; von Haehling, S.; Okonko, D.O.; Jankowska, E.A.; Poole-Wilson, P.A.; Anker, S.D. Fluvastatin reduces increased blood monocyte toll-like receptor 4 expression in whole blood from patients with chronic heart failure. Int. J. Cardiol. 2008, 124, 80-85. [CrossRef] [PubMed]

207. Hodgkinson, C.P.; Ye, S. Statins inhibit toll-like receptor 4-mediated lipopolysaccharide signaling and cytokine expression. Pharmacogenet. Genom. 2008, 18, 803-813. [CrossRef] [PubMed]

208. Sanchez-Lemus, E.; Murakami, Y.; Larrayoz-Roldan, I.M.; Moughamian, A.J.; Pavel, J.; Nishioku, T.; Saavedra, J.M. Angiotensin II AT1 receptor blockade decreases lipopolysaccharide-induced inflammation in the rat adrenal gland. Endocrinology 2008, 149, 5177-5188. [CrossRef] [PubMed]

209. Dasu, M.R.; Riosvelasco, A.C.; Jialal, I. Candesartan inhibits toll-like receptor expression and activity both in vitro and in vivo. Atherosclerosis 2009, 202, 76-83. [CrossRef] [PubMed]

210. Zittermann, A. The biphasic effect of vitamin D on the musculoskeletal and cardiovascular system. Int. J. Endocrinol. 2017, 2017, 1-11. [CrossRef] [PubMed] 
211. Hartley, L.; Clar, C.; Ghannam, O.; Flowers, N.; Stranges, S.; Rees, K. Vitamin K for the primary prevention of cardiovascular disease. Cochrane Database Syst. Rev. 2015. [CrossRef]

212. Gast, G.C.M.; de Roos, N.M.; Sluijs, I.; Bots, M.L.; Beulens, J.W.J.; Geleijnse, J.M.; Witteman, J.C.; Grobbee, D.E.; Peeters, P.H.M.; van der Schouw, Y.T. A high menaquinone intake reduces the incidence of coronary heart disease. Nutr. Metab. Cardiovasc. Dis. NMCD 2009, 19, 504-510. [CrossRef] [PubMed]

213. Cranenburg, E.C.M.; Schurgers, L.J.; Vermeer, C. Vitamin K: The coagulation vitamin that became omnipotent. Thromb. Haemost. 2007, 98, 120-125. [CrossRef] [PubMed]

214. Erkkilä, A.T.; Booth, S.L.; Hu, F.B.; Jacques, P.F.; Manson, J.E.; Rexrode, K.M.; Stampfer, M.J.; Lichtenstein, A.H. Phylloquinone intake as a marker for coronary heart disease risk but not stroke in women. Eur. J. Clin. Nutr. 2005, 59, 196-204. [CrossRef] [PubMed]

215. Erkkilä, A.T.; Booth, S.L.; Hu, F.B.; Jacques, P.F.; Lichtenstein, A.H. Phylloquinone intake and risk of cardiovascular diseases in men. Nutr. Metab. Cardiovasc. Dis. NMCD 2007, 17, 58-62. [CrossRef] [PubMed]

216. Erkkilä, A.T.; Booth, S.L. Vitamin K intake and atherosclerosis. Curr. Opin. Lipidol. 2008, 19, 39-42. [CrossRef] [PubMed]

217. Geleijnse, J.M.; Vermeer, C.; Grobbee, D.E.; Schurgers, L.J.; Knapen, M.H.J.; van der Meer, I.M.; Hofman, A.; Witteman, J.C.M. Dietary intake of menaquinone is associated with a reduced risk of coronary heart disease: The rotterdam study. J. Nutr. 2004, 134, 3100-3105. [PubMed]

218. Van Ballegooijen, A.J.; Pilz, S.; Tomaschitz, A.; Grübler, M.R.; Verheyen, N. The synergistic interplay between vitamins $\mathrm{D}$ and $\mathrm{K}$ for bone and cardiovascular health: A narrative review. Int. J. Endocrinol. 2017, 2017, 1-12. [CrossRef]

219. Braam, L.A.J.L.M.; Hoeks, A.P.G.; Brouns, F.; Hamulyák, K.; Gerichhausen, M.J.W.; Vermeer, C. Beneficial effects of vitamins $\mathrm{D}$ and $\mathrm{K}$ on the elastic properties of the vessel wall in postmenopausal women: A follow-up study. Thromb. Haemost. 2004. [CrossRef] [PubMed]

220. Shea, M.K.; O’Donnell, C.J.; Hoffmann, U.; Dallal, G.E.; Dawson-Hughes, B.; Ordovas, J.M.; Price, P.A.; Williamson, M.K.; Booth, S.L. Vitamin K supplementation and progression of coronary artery calcium in older men and women. Am. J. Clin. Nutr. 2009, 89, 1799-1807. [CrossRef] [PubMed]

221. Wang, Z.; Wang, Z.; Zhu, J.; Long, X.; Yan, J. Vitamin K2 can suppress the expression of toll-like receptor 2 (TLR2) and TLR4, and inhibit calcification of aortic intima in $A p o E^{-/-}$mice as well as smooth muscle cells. Vascular 2017. [CrossRef] [PubMed]

222. Pan, M.-H.; Maresz, K.; Lee, P.-S.; Wu, J.-C.; Ho, C.-T.; Popko, J.; Mehta, D.S.; Stohs, S.J.; Badmaev, V. Inhibition of TNF- $\alpha$, IL- $1 \alpha$, and IL-1 $\beta$ by Pretreatment of Human Monocyte-Derived Macrophages with Menaquinone-7 and Cell Activation with TLR Agonists In Vitro. J. Med. Food 2016, 19, 663-669. [CrossRef] [PubMed]

(C) 2017 by the author. Licensee MDPI, Basel, Switzerland. This article is an open access article distributed under the terms and conditions of the Creative Commons Attribution (CC BY) license (http://creativecommons.org/licenses/by/4.0/). 